\title{
Application and Evaluation of Energy Conservation Technologies in Wastewater Treatment Plants
}

\author{
Yongteng Sun ${ }^{1, *} \mathbb{D}$, Ming Lu ${ }^{1, *}$, Yongjun Sun ${ }^{2} \mathbb{D}$, Zuguo Chen ${ }^{1}$, Hao Duan ${ }^{1}\left(\mathbb{D}\right.$ and Duan Liu ${ }^{1}$ \\ 1 School of Information and Electrical Engineering, Hunan University of Science and Technology, Xiangtan \\ 411201, China; zuguochen@csu.edu.cn (Z.C.); tcbgsn@gmail.com (H.D.); duanliu9@gmail.com (D.L.) \\ 2 College of Urban Construction, Nanjing Tech University, Nanjing 211800, China; sunyongjun@njtech.edu.cn \\ * Correspondence: tasselsun@gmail.com (Y.S.); mlu@hnust.edu.cn (M.L.)
}

Received: 30 September 2019; Accepted: 21 October 2019; Published: 24 October 2019

Featured Application: This review introduces some energy-saving technologies of wastewater treatment. This work can provide some help for those who are engaged in energy conversation and energy efficiency research of wastewater treatment.

\begin{abstract}
High energy consumption is an important issue affecting the operation and development of wastewater treatment plants (WWTPs). This paper seeks energy-saving opportunities from three aspects: energy application, process optimization, and performance evaluation. Moreover, effective energy-saving can be achieved from the perspective of energy supply and recovery by using green energy technologies, including wastewater and sludge energy recovery technologies. System optimization and control is used to reduce unnecessary energy consumption in operation. Reasonable indexes and methods can help researchers evaluate the application value of energy-saving technology. Some demonstration WWTPs even can achieve energy self-sufficiency by using these energy conservation technologies. Besides, this paper introduces the challenges faced by the wastewater treatment industry and some emerging energy-saving technologies. The work can give engineers some suggestions about reducing energy consumption from comprehensive perspectives.
\end{abstract}

Keywords: wastewater treatment; green energy; energy conservation

\section{Introduction}

\subsection{Wastewater Treatment Plant}

The growth of the population and the development of economy make water pollution more common than ever before. Nearly $80 \%$ of the world's population is facing serious water security threats, and the world will face a $40 \%$ water deficit by 2030 [1,2]. To deal with the challenge of water pollution, the European Union promulgated the Water Framework Directive to provide some guidance in water basin management and water quality restoration [3]. However, the instruction can only provide guidance, and sewage still needs to be treated to achieve water quality recovery. In order to protect the living environment of human beings, it is necessary to purify the wastewater and remove the pollutants in the wastewater.

According to the different treatment objectives, wastewater treatment processes can be divided into three levels to select the appropriate treatment methods. The primary treatment uses physical methods like screening, interception, and gravity separation to remove suspended solids (SS), fat, and grease in wastewater [4]. The removal rate of biochemical oxygen demand (BOD) is only $30-40 \%$ and SS is $50-60 \%$ in primary treatment [5-7]. Secondary treatment, the main body of wastewater treatment, uses biological treatment and some chemical treatment methods to remove degradable organic matter 
and some colloidal pollutants from wastewater [8]. The activated sludge method is a biochemical combination method, which is the most widely used method for secondary treatment of wastewater [9]. Tertiary treatment is used to remove pollutants that cannot be removed by secondary treatment such as $\mathrm{P}, \mathrm{N}$, and biodegradable organic pollutants.

WWTPs enrich pollutants into sludge, which contains many organic substances and pathogens while purifying wastewater. Sludge treatment is a process of sludge stabilization, reduction, and harmless treatment, including sludge drying, aerobic, anaerobic digestion, and adding chemical agents. Sludge disposal is the process of reasonable storage and resource utilization [6]. Sludge disposal mainly includes sludge landfill, land use, composting and thermochemical treatment technology. Common wastewater and sludge (WW\&S) treatment processes are shown in Figure 1.

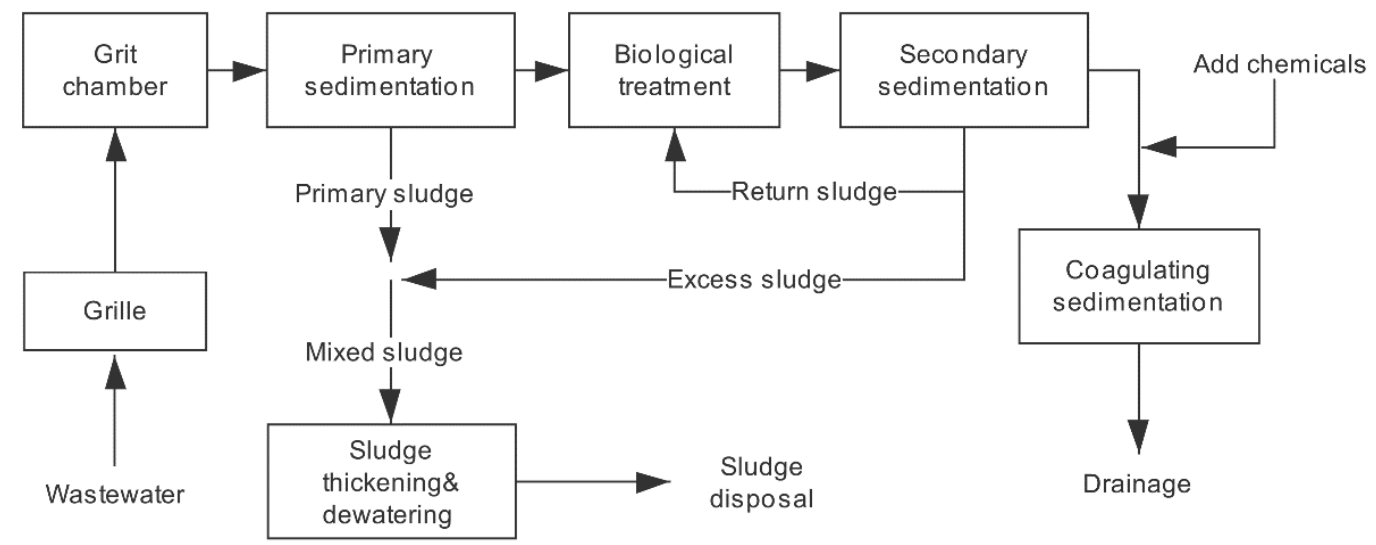

Figure 1. Flow chart of common wastewater and sludge (WW\&S) treatments.

\subsection{Current Energy Consumption of WWTPS}

Due to stricter effluent limits and rapid population growth, high energy consumption becomes serious and cannot be ignored [10]. The energy consumption cost accounts for $20-40 \%$ of the operation costs, and electrical consumption accounts for $60-90 \%$ of the total energy consumption in WWTPs [11-14]. For this reason, the energy consumption of WWTPs is generally described by electrical consumption. The electricity consumption of WWTPs in Europe is about $27 \mathrm{TWh} /$ year, according to Eurostat's assessment in $2015[15,16]$. It is estimated that $3-4 \%$ of the electricity used in the United States is for municipal wastewater treatment, equivalent to $56 \mathrm{TWh} /$ year [17]. The proportion of China's energy consumption associated with WWTPs is about $0.25 \%[18,19]$. In some European countries, such as Sweden, Germany, and Spain, the consumption of WWTPs account for $0.7-1 \%$ of national energy consumption [18-20]. To solve the problem, EU amends Directives 2009/125/EC and 2010/30/EU, with a view to promoting energy efficiency within the EU and establishing concrete actions to achieve the expected energy savings [21].

Wastewater treatment is an energy-intensive industry that is bedeviled with high energy consumption [22]. Most WWTPs can reduce energy input by $30 \%$ or more by adopting energy-saving measures and adjusting the treatment process [23]. Therefore, it is valuable to study the energy-saving technologies of wastewater treatment.

\subsubsection{Energy Intensity and Benchmark}

Researchers use benchmarks and energy intensity (EI) to evaluate WWTP energy efficiency, which is an important prerequisite for energy consumption research [24]. Benchmark methods include data envelopment analysis, energy analysis, and pollutant removal efficiency analysis [25]. Compared with the benchmark, EI is simple and easy. A commonly used EI is the energy consumption per unit of pollutant removal, which can be subdivided into energy consumption of population equivalents, chemical oxygen demand (COD) removal, SS removal and total nitrogen (TN) removal, etc. $[14,26]$. 
However, the single type of pollutant removal is not comprehensive enough for power consumption evaluation [27].

The energy consumption per unit volume of wastewater treated, widely used in China, which ignores the difference in wastewater quality [28]. Using the EI to analyze the average energy consumption of wastewater treatment in different countries can find some problems. The average energy consumption of urban WWTPs in the United States is $0.20 \mathrm{kWh} / \mathrm{m}^{3}$, while the consumption of Chinese is $0.27 \mathrm{kWh} / \mathrm{m}^{3}$, the consumption of Japanese is $0.26 \mathrm{kWh} / \mathrm{m}^{3}$, the consumption of United Kingdom is $0.62 \mathrm{kWh} / \mathrm{m}^{3}$ [29-31]. The difference in energy density in these countries is caused by many influencing factors.

\subsubsection{Influencing Factors}

The relationship between influencing factors and the energy consumption is also significant. Many studies show that the scale, treatment processes, effluent discharge standards, and wastewater quality can affect energy consumption [28,32]. Therefore, it is not advisable to study the energy consumption of wastewater treatment alone, and it is more practical to compare the energy consumption of wastewater treatment process horizontally [33].

Jiang et al. made statistics on the factors affecting energy consumption. He found that process, scale, and water quality were the key factors affecting energy consumption [34]. The influence of effluent quality on energy consumption is intuitive and easy to understand. Energy consumption is positively correlated with effluent water quality standards [28]. The unit energy consumption of WWTPs with the same process and scale increases with the improvement of effluent quality, which is consistent with conclusion of Han [34]. Some researchers hold the opinion that the expansion of the WWTP scale helps to reduce unit energy consumption $[35,36]$. However, Han et al. found that unit energy consumption would have a reverse increase if scale exceeded the boundary [28]. Han et al. attributed it to the friction between the wastewater and the pipeline when the wastewater was transported. There is no doubt that treatment processes have a great effect on energy consumption. A typical WWTP, where aerobic activated sludge treatment and anaerobic sludge digestion technology is applied, consumes $0.6 \mathrm{kWh} / \mathrm{m}^{3}$ electrical energy for wastewater treatment [37]. Wastewater treatment using lagoons, trickling filters, activated sludge and advanced wastewater treatment requires 0.09-0.29, $0.18-0.42,0.33-0.60$, and $0.31-0.40 \mathrm{kWh} / \mathrm{m}^{3}$, respectively [38]. The energy consumption of WWTPs under different factors (locations, processes) is shown in Table 1. Different countries and treatment methods will have a great impact on energy consumption.

Table 1. Energy consumption of wastewater treatment in different countries and processes.

\begin{tabular}{cccc}
\hline Countries & Processes & Consumption/Wastewater $\left(\mathbf{k W h} / \mathbf{m}^{3}\right)$ & Reference \\
\hline \multirow{3}{*}{ China } & SBR & 0.22711 & {$[34]$} \\
& Activated sludge & 0.24408 & {$[34]$} \\
& Oxidation ditch & 0.26254 & {$[34]$} \\
\hline \multirow{2}{*}{ Japan } & Oxidation ditch & $0.44-2.07$ & {$[39]$} \\
& Activated sludge & $0.3-1.89$ & {$[39]$} \\
\hline \multirow{2}{*}{ Australia } & Oxidation ditch & $0.5-1.0$ & {$[40]$} \\
& Activated sludge & 0.46 & {$[40]$} \\
\hline \multirow{2}{*}{ USA } & Activated sludge & $0.33-0.60$ & {$[40]$} \\
\hline
\end{tabular}

Similarly, the aging factor, climate, function, location, and other influencing factors were taken into consideration by researchers [41,42]. However, these factors are less influential. Yan et al. investigated energy consumption of WWTPs in different regions of China and found that there were significant differences among different regions [28]. They believe that this result is due to the difference in climate, treatment process, effluent standard, scale, and other related factors. Location is not a direct factor in energy consumption. 


\subsubsection{The Distribution of Energy Consumption in WWTPs}

In order to find opportunities to save energy, it is necessary to find out where the power is consumed. WWTPs usually have primary, secondary and advanced treatment stages. Compared with other stages, energy consumption in the primary treatment stage is lower [18]. The consumption of secondary treatment depends on the method used, which is shown in Table 1. Advanced treatment requires much energy consumption to remove nutrients.

The energy of WWTPs which use activated sludge is mainly consumed in the three processes, the oxygen supply and aeration (50-60\%), the treatment and disposal of sludge (10-25\%), and the secondary sedimentation (15\%) [43]. Auxiliary buildings and the lighting of factories also consume small amounts of electricity. The energy consumption of aeration and wastewater upgrade accounts for the vast majority of WWTPs, which is also the key point of energy performance optimization for WWTPs. Generally speaking, most of the energy of wastewater treatment is spent on the treatment of some major pollutants, especially the stabilization and harmlessness of organic matter.

\subsection{Structure of the Review}

The problem of high energy consumption in WWTPs has attracted much attention. The purpose of writing this review is to find opportunities for energy-saving and consumption reduction from the perspective of external energy use, internal energy recovery, system optimization, and performance evaluation. It is a relatively complete system from the perspective of energy. To make the article clearer, the main contents of each section are listed:

- Section 1: The present situation of energy consumption in WWTPs is introduced to find energy-saving opportunities.

- Section 2: The applications of green energy (solar energy, wind energy, wastewater, and sludge energy recovery) is an important energy-saving technology in WWTPs. This section introduces specific technologies and applications.

- Section 3: As a significant component of energy-saving technologies, optimization and control of the wastewater treatment system (control algorithm, measurement, and implementation, model, decision-making) are introduced.

- Section 4: Indexes and methods are helpful to evaluate the performance of WWTPs and energy-saving technologies. The selection of indexes and methods needs comprehensive consideration.

- Section 5: Some challenges in the industry and some emerging technologies (Internet of things, pretreatment, energy self-sufficiency) which will bring new solutions to the high energy consumption are discussed.

- Section 6: A brief summary of the review is given.

\section{Green Energy Utilized in WWTPs}

In order to solve the problem of high energy consumption, the application of green energy to WWTPs is a direct and effective treatment scheme. Green energy includes not only external energy such as solar energy and wind energy but also energy recovered from wastewater and sludge. The application of green energy is an important means for WWTPs to reduce energy consumption [44-47].

\subsection{Solar Energy and Photovoltaic (PV) Energy}

Solar energy refers to the solar radiation that reaches the earth in the form of the electromagnetic waveform. As an important energy green resource, solar energy is abundant, renewable, clean, safe and easy to access. Solar energy is one of the most widely used green energy sources in WWTPs [48]. The form of solar energy used in WWTPs is shown in Table 2. 
Table 2. Applications of solar energy in wastewater treatment plants (WWTPs).

\begin{tabular}{cccc}
\hline Progresses & Types & Technologies & Reference \\
\hline Electricity generation & Light utilization & PV power generation & {$[49,50]$} \\
\hline \multirow{3}{*}{ Wastewater treatment } & Physical treatment & Ultraviolet disinfection & {$[49]$} \\
& Biological treatment & Solar artificial wetlands & {$[51]$} \\
& Chemical treatment & AOPS; Reverse osmosis & {$[52,53]$} \\
\hline
\end{tabular}

Solar PV power generation is a method of converting light energy into electric energy through semiconductor materials. With the improvement of solar energy conversion efficiency and the reduction of the cost of solar panels, PV is becoming more and more widespread used. Many WWTPs use PV to supply electricity to the treatment plant because their aeration tanks and other places have a huge available space for PV equipment. A 100-kW photovoltaic system was installed on the roof of the Kiheung Respia WWTP in Korea, which was estimated to produce a maximum of $155 \mathrm{MW}$ h/year [44]. However, short lifespan and high construction costs of PV equipment limit the development of PV in WWTPs.

Solar energy disinfection mainly uses ultraviolet rays in sunlight to kill bacteria in wastewater [49]. It is noteworthy that PV power generation mainly uses visible light, so some WWTPs directly combine PV power generation with ultraviolet disinfection [51]. In solar artificial wetlands powered by $\mathrm{PV}$ or solar heat, wastewater is discharged into the wetland for physical and biological treatment. Although the technology is simple and its cost (investment and operation) is low, it cannot deal with much wastewater. Advanced oxidation processes (AOPs) are chemical reactions that oxidize pollutants are removed via oxidation by highly reactive radicals [54]. It can degrade natural toxins, emerging pollutants, pesticides, and other harmful pollutants efficiently. The application of solar energy in AOPs mainly includes solar Fenton and photocatalytic oxidation. Munoz et al. assessed AOPs and found that AOPs mainly depend on the consumption of electric energy. They found that the use of solar energy can reduce environmental impacts by $90 \%$ [55]. Pretreatment technology, especially preheating, has attracted much attention in water treatment. Pretreatment can be used for wastewater treatment technologies like anaerobic digestion and reverse osmosis [56,57]. Solar heating can be used as a part of pretreatment, which can save energy that should be consumed in the original process.

\subsection{Wind Energy}

Wind energy, a significant part of green energy, is kinetic energy produced by air flow under solar radiation. Wind energy is widely distributed and abundant in reserves. It is especially important for islands and areas that are far away from the main power grid. For the poor stability and randomness of wind energy itself, it is difficult to use it alone for the power supply of WWTPs. To make up for the shortcomings of wind energy and solar power generation, wind power is mainly combined with solar energy in WWTPs under the current technical conditions, which can realize wind-solar complementary power generation to supply energy to WWTPs [58,59]. This technology has been widely used in the field of wind energy utilization $[60,61]$.

\subsection{Energy Recovery of WWES}

WW\&S contains a lot of energy and resources, which should be used reasonably. Nutrients ( $\mathrm{N}$ and $P$ ) and energy (C) are feasible components of recycling [62]. This review introduces the energy recovery technology of WW\&S from three aspects: heat energy, biomass, and its derivative energy, chemical energy. Heat energy mainly comes from waste heat of wastewater. Chemical energy comes from heat energy released by chemical reaction or reaction products, which can be used to generate electricity. Biomass energy needs biomass as the carrier of reaction. Microalgae can store solar energy and carbon (form wastewater) while absorbing nutrients, which allows it to store a large amount of biomass energy. 
Table 3 shows some available energy and utilization ways in WW\&S. Most of the recovered energy is used in many processes of WWTPs, which makes energy self-sufficiency possible [45,46]. For example, biogas can be used to maintain the system temperature at $35^{\circ} \mathrm{C}$ or $55^{\circ} \mathrm{C}$, which is conducive to medium-temperature digestion or high-temperature digestion $[63,64]$.

Table 3. Some available energy and utilization ways in WW\&S.

\begin{tabular}{cccc}
\hline Energy in WW\&S & Technologies & Applications & Reference \\
\hline Heat energy & Wastewater source heat pump & Sludge drying, Heating & {$[65]$} \\
\hline \multirow{2}{*}{ Biomass energy } & $\begin{array}{c}\text { Microalgae culture, Anaerobicdigestion, } \\
\text { Microbial fuel cell }\end{array}$ & Fuel production, Power generation & {$[58,66,67]$} \\
\hline Chemical energy & Thermochemistry & Fuel production, Power generation & {$[68]$} \\
\hline
\end{tabular}

\subsubsection{Heat Energy and Wastewater Source Heat Pump}

It was estimated that 350 TWh of energy was lost annually through building water discharge with a notable potential for heat recovery [69]. Wastewater source heat pump (WWSHP) technology is the main way to utilize heat energy in addition to solar energy in wastewater treatment. It can supply cooling and heating to the outside through the refrigerant state cycle inside the unit [70]. The application of WWSHP is currently used in WWTPs, such as sludge drying, reactor heating and so on [71]. Figure 2 is a common structure chart of WWSHP.

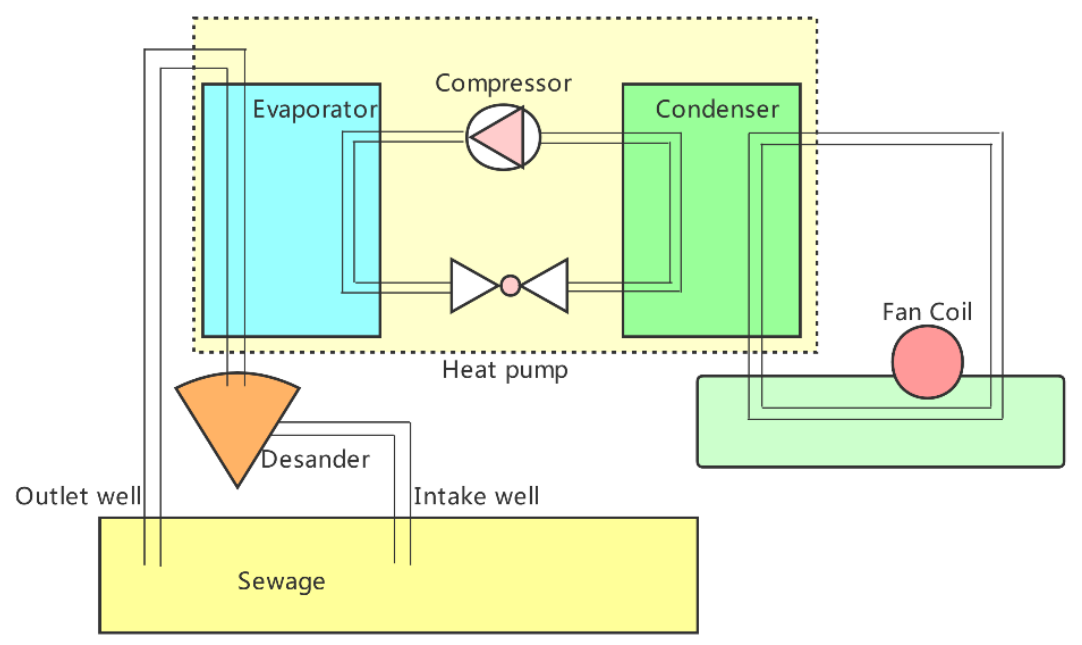

Figure 2. Common structure chart of the wastewater source heat pump (WWSHP).

WWSHP mainly uses urban wastewater as the cold and heat source for energy extraction and storage. Wastewater temperature is $3-5^{\circ} \mathrm{C}$ higher than that of groundwater when heating, and $10-15^{\circ} \mathrm{C}$ lower than that of air when cooling. The coefficient of performance values of the reviewed studies ranges from 1.77 to 10.63 for heating and 2.23 to 5.35 for cooling based on the experimental and simulated values [72]. In addition to energy-saving and economic benefits, WWSHP also has environmental benefits. Recovering heat energy from wastewater can reduce the utilization of coal and other energy sources, which can reduce the generation of pollutants such as $\mathrm{NO}_{\mathrm{x}}, \mathrm{SO}_{\mathrm{x}}$ and dust.

Although it has various advantages, WWSHP also has some problems to be solved. Firstly, wastewater will pollute heat exchangers. Scaling and corrosion will damage the equipment and decrease the coefficient of performance of the system. Secondly, most of the WWTPs and WWSHP stations are far away from the city which makes the heat pump system far away from the users, increasing the energy consumption for transportation. However, with the development of monitoring technology and control technology, WWSHP has a bright future. 


\subsubsection{Biomass and Its Derivative Energy}

Biomass energy is a kind of clean and safe energy with abundant reserves. It comes from biomass that stores solar energy as chemical energy. Biomass is expected to contribute to half of the EU renewable energy targets according to the Renewable Energy Directive, while a large amount of biomass energy comes from WW\&S [73,74]. The application technology of biomass and its derived energy in WWTPs mainly includes the following aspects: cultivation of microalgae in wastewater, production of biogas by anaerobic digestion (AD) and microbial fuel cell technology (MFC).

The wastewater treatment with microalgae has recently attracted more and more attention for its energy conservation, low cost, effective nutrient removal ability, fixing $\mathrm{CO}_{2}$ ability, and its good economic benefits. Cultivation of microalgae has low requirements for water quality, and it absorbs nutrients $(\mathrm{N}, \mathrm{P})$ and the organic carbon source during the growth process. Feng et al. used ordinary chlorella to simulate the removal of $\mathrm{N}$ from the secondary treatment effluent. After 2 days, the $\mathrm{N}$ removal rate reached $90 \%$, and the $P$ removal rate was $94 \%$ [75]. The microalgae also have economic benefits and are widely used in fertilizer, feed, and other agricultural fields. The bio-oil produced by hydrothermal liquefaction of microalgae has also attracted extensive attention. Two demonstration-scale algae-based facilities of the USA are expected to produce 5 million gallons of fuel per year [76].

$\mathrm{AD}$, the most popular sludge stabilization technology, is carried out under the conditions of an anaerobic environment. The process transforms sludge organic solids to biogas, which is a mixture of $\mathrm{CH}_{4}, \mathrm{CO}_{2}$, and traces of other gases at medium temperature $\left(30-36{ }^{\circ} \mathrm{C}\right)$ or high temperature $\left(50-55^{\circ} \mathrm{C}\right.$ ) [62,77]. Biogas contains $50-70 \% \mathrm{CH}_{4}$ and $30-50 \% \mathrm{CO}_{2}$, traces of other gases (such as $\mathrm{H}_{2}$, $\mathrm{H}_{2} \mathrm{~S}$, and $\mathrm{N}_{2}$ ) [47]. The calorific value of the biogas produced by $\mathrm{AD}$ is about $21-25 \mathrm{MJ} / \mathrm{m}^{3}[6,78]$. This biogas can be utilized as a source of energy in the production of electricity. The total installed capacity of the EU's biogas plants in 2010 exceeded $6.1 \mathrm{GW}$, of which 9.9\% came from WW\&S [79]. The study of Gollet et al. shows that biogas slurry contains nutrients necessary for the growth of microalgae, which is suitable for microalgae cultivation [80]. It can solve the problem of the treatment of biogas slurry produced by AD effectively. Data from Spanish WWTPs show that AD can recover $52 \%$ of the energy in sludge through biogas [81].

The microbial fuel cell (MFC) is a novel wastewater treatment technology that uses microorganisms as biocatalysts to oxidize organic matter and transfer electrons from substrate oxidation to the anodic surface for bioelectricity production [82]. Mixed bacteria can be used to biodegrade organic wastes into $\mathrm{CO}_{2}, \mathrm{H}_{2} \mathrm{O}$, and generate electricity at the same time. Zhang et al. applied MFCs to a municipal WWTP and tracked it for a long time, finding it removed 65-70\% COD at $11 \mathrm{~h}$ and reduced about 50\% SS [83]. Dentel et al. investigated the possibility of the application of an MFC in sludge treatment and achieved a maximum voltage of $517 \mathrm{mV}$ through anaerobically digested [84]. Due to the low voltage generated by MFC, there is still a long way to go for the large-scale application of MFC power generation.

\subsubsection{Thermochemical Treatment and Organic Fuel Production}

WW\&S contains enormous amounts of chemical energy. Traditional sludge compost and landfill will not only cause secondary pollution but also waste a lot of energy [85]. Research about measuring the chemical energy of municipal wastewater shows that chemical energy in municipal wastewater can reach $26.4 \mathrm{~kJ} / \mathrm{g}$ COD [86]. These chemical energies can be utilized by thermochemical treatment. According to the environment of the redox reaction, the common thermochemical treatment technologies of sludge can be divided into three categories: aerobic (incineration, wet air oxidation), anoxic (gasification) and anaerobic (liquefaction, pyrolysis) treatment [87]. A comparison of several thermochemical reactions is shown in Table 4. 
Table 4. Comparison of several thermochemical reactions.

\begin{tabular}{ccccc}
\hline Processes & Reaction Conditions & Main Products & Main Pollutions & Reference \\
\hline Incineration & $\begin{array}{c}\text { Auxiliary fuel, } \\
\text { Aerobic atmosphere }\end{array}$ & $\backslash$ & $\begin{array}{c}\text { Fly ash, } \mathrm{SO}_{2}, \mathrm{SO}_{3,}, \\
\mathrm{NO}_{x}, \text { Heavy metals }\end{array}$ & {$[62,87]$} \\
\hline Wet air oxidation & $\begin{array}{c}\text { Oxidation, } 125-320{ }^{\circ} \mathrm{C} \\
0.5-20 \mathrm{MPa}\end{array}$ & Bio-gas & $\backslash$ & {$[88]$} \\
\hline Gasification & $\begin{array}{c}\text { Anoxic (non-combustion) } \\
\text { atmosphere, } 1000-1150{ }^{\circ} \mathrm{C}\end{array}$ & Bio-gas & $\begin{array}{c}\mathrm{H}_{2} \mathrm{~S}, \mathrm{SO}_{2}, \text { Other } \\
\text { polluted gases }\end{array}$ & {$[89,90]$} \\
\hline $\begin{array}{c}\text { Hydrothermal } \\
\text { liquefaction }\end{array}$ & $250-400{ }^{\circ} \mathrm{C}, 4-22 \mathrm{MPa}$ & $\begin{array}{c}\text { Bio-oil, Gas, } \\
\text { Water-soluble product }\end{array}$ & $\begin{array}{c}\text { Liquefaction } \\
\text { wastewater }\end{array}$ & {$[91,92]$} \\
\hline Pyrolysis & $\begin{array}{c}\text { Anoxic atmosphere, } \\
400-800{ }^{\circ} \mathrm{C}\end{array}$ & $\begin{array}{c}\text { Bio-char, Bio-oil, } \\
\text { Bio-gas }\end{array}$ & $\begin{array}{c}\text { Pyrolysis } \\
\text { wastewater }\end{array}$ & {$[89]$} \\
\hline
\end{tabular}

Sludge is mainly composed of organic matter with the calorific value, so it can be incinerated with auxiliary fuel to reduce the number of bacteria and oxidize toxic pollutants. The calorific value of dry sewage sludge is about $12-20 \mathrm{MJ} / \mathrm{kg}$, equivalent to that of lignite $(11.7-15.8 \mathrm{MJ} / \mathrm{kg})[78,93]$. The process of incineration can be used for thermal power generation, and the ash can be used as building materials or adsorption materials. Some WWTPs with sludge incineration facilities are expected to generate 2.0 MW of electricity, which can provide $20 \%$ of their energy needs [62]. Sludge incineration has been widely used for power generation in Portland [87]. However, sludge incineration tail gas will also bring secondary pollution.

Wet air oxidation is useful for the treatment of hazardous, toxic, and nonbiodegradable waste streams [88]. It is a liquid-phase reaction between organic material in $\mathrm{H}_{2} \mathrm{O}$ and $\mathrm{O}_{2}$, which does not produce $\mathrm{NO}_{x}, \mathrm{SO}_{2}$, dioxins, furans, and fly ash [94]. Under these conditions, organic compounds are mainly oxidized into $\mathrm{CO}_{2}, \mathrm{H}_{2} \mathrm{O}$, and simple biodegradable substances. However, wet air oxidation has many shortcomings, such as corrosion, odor problems and high energy consumption [62,95]. More than 400 wet air oxidation plants are operating around the word to treat wastewater from petrochemical, chemical and pharmaceutical industries and residual sludge from biological treatment plants [96].

Compared with pyrolysis, gasification requires the participation of water and oxygen. The dry sludge is decomposed into bio-gas and bio-char in reducing atmosphere. Data from the Mannheim demonstration plant shows that $\mathrm{CO}, \mathrm{H}_{2}$ and $\mathrm{CH}_{4}$ account for $13.8 \%, 13.3 \%$ and $4.2 \%$ of gasification gas, respectively. The calorific value of gasification gas is $4.7 \mathrm{MJ} / \mathrm{m}^{3}$, which is close to the result of other research (about $4 \mathrm{MJ} / \mathrm{m}^{3}$ ) [93,97]. Gasification can generate high-quality fuel gas, but it is limited by high energy consumption [89].

Gollakota et al. summarized the literature pertained to hydrothermal liquefaction of biomass and found that the bio-oil produced by hydrothermal liquefaction has a high calorific value of 20-40 MJ/kg [91]. Hydrothermal liquefaction can break down cell structures, as well as destroy metastable systems and change their sedimentation equilibrium in sludge. Compared with the traditional method of using dry sludge, using wet sludge can reduce energy consumption by $30 \%[98,99]$. However, the quality of the oil produced by this technology is not high and the waste hydrothermal liquefaction wastewater also needs to be treated.

The research of Font et al. shows that the proportion of gas, liquid, and solid in sludge pyrolysis products is $10.7-26.6 \%, 23.5-40.7 \%$, and $46.1-60.3 \%$ [100]. The main components of pyrolysis gas are $\mathrm{H}_{2}, \mathrm{CH}_{4}, \mathrm{CO}, \mathrm{CO}_{2}, \mathrm{~N}_{2}$, etc. Pyrolysis conditions, such as heating rate and final pyrolysis temperature, affected the composition of pyrolysis products [101]. The average calorific value of pyrolysis gas is about $12-13 \mathrm{MJ} / \mathrm{m}^{3}$ and the maximum calorific value can reach $25 \mathrm{MJ} / \mathrm{m}^{3}$ in Inguanzo et al.'s research [101]. Bio-oil is mainly composed of $\mathrm{C}, \mathrm{H}, \mathrm{N}, \mathrm{S}$, and $\mathrm{O}$, where $\mathrm{C}$ is about $70 \%, \mathrm{H}$ is about $9 \%$. It has a high calorific value and can be used as fuel or raw material for chemical industry production. Bio-char can be used to make adsorbents, catalysts, or industrial materials. Bio-Char also has a calorific value, which is about $5 \mathrm{MJ} / \mathrm{kg}$ [93]. 
Compared with incineration and gasification, pyrolysis seems to be the best choice of thermochemical treatment. Pyrolysis has been used as an alternative technology for incineration and is expected to become the main technology in WWTPs in recent years because it has less pollution and higher economic benefits. However, there are some problems in pyrolysis technology, such as high energy consumption of pyrolysis and low fuel quality.

\section{Wastewater Treatment System Optimization and Control}

Wastewater treatment construction, management, operation, and control can be boiled down as a complete system. Putting energy conservation technologies in energy and recovery aside, such as green energy utilization in Section 2, there are many energy conservation opportunities in the whole system. This section introduces some technologies of energy conservation and cost reduction from the perspective of system optimization. The purpose of system optimization is to improve the monitoring and automatic level of WWTPs, reducing energy consumption and operating costs. Process, measurement, decision-making, and implementation are four components of system optimization [102]. Wastewater treatment processes are non-linear, and its parameters are interrelated, so control, monitoring, and model are very meaningful to reduce energy consumption [103].

\subsection{Process Control}

There are many factors that affect the control effect, such as the accuracy of data acquisition, data transmission speed, reference model, execution components and so on. These factors are mostly limited by equipment and models and will be studied in Sections 3.2 and 3.3. This section mainly discusses the specific control algorithms and technologies that can realize energy conservation in wastewater treatment. Compared with measurement and implementation, process control with modifying algorithms can reduce energy consumption, improve efficiency and automatic level without upgrading equipment. Table 5 shows some examples of using optimization algorithms to adjust different control processes.

Table 5. Some examples of using optimization algorithms to adjust different control processes.

\begin{tabular}{|c|c|c|c|c|}
\hline Processes & Control Object & Algorithms & Achievements & Reference \\
\hline Secondary settler & Sludge height & Fuzzy algorithm & $\begin{array}{l}\text { Reduce SS concentration } \\
\text { fluctuations }\end{array}$ & [104] \\
\hline Nutrient removal & Nutrient removal & Neural networks & $\begin{array}{c}\text { Remove more than } 95 \% \text { of organic } \\
\text { matters and more than } 60 \% \text { of } \mathrm{N} \\
\text { and } \mathrm{P}\end{array}$ & [105] \\
\hline Flows & $\begin{array}{l}\text { Flows, Water levels, } \\
\text { Overflow }\end{array}$ & $\begin{array}{l}\text { Global optimal } \\
\text { control }\end{array}$ & $\begin{array}{c}\text { Decrease combined sewer } \\
\text { overflow volumes at four } \\
\text { overflow sites by more than } 85 \%\end{array}$ & [106] \\
\hline Aeration & Dissolved oxygen & $\begin{array}{l}\text { Model predictive } \\
\text { control }\end{array}$ & $\begin{array}{l}\text { Decreased the integral of absolute } \\
\text { error with more than } 40 \%\end{array}$ & [107] \\
\hline Aeration & Dissolved oxygen & Hybrid NMPC & $\begin{array}{l}\text { Maintain Do level } 2 \mathrm{mg} / \mathrm{L} \text {, Control } \\
\text { signals are exact and instant }\end{array}$ & [108] \\
\hline Aeration & Dissolved oxygen & Genetic algorithm & $\begin{array}{c}\text { Pollution load and energy } \\
\text { consumption savings can reach up } \\
\text { to } 10 \%\end{array}$ & [109] \\
\hline Aeration & Dissolved oxygen & Fuzzy algorithm & Save energy about $10-40 \%$ & [110] \\
\hline Aeration & Dissolved oxygen & Fuzzy algorithm & Save about $40 \%$ of the energy & [111] \\
\hline
\end{tabular}

There are many kinds of unit-process control, such as dissolved oxygen (DO) control, solids retention time (SRT) control, return activated sludge flow control, and chemical precipitation control [112]. The process of aeration consumes the most energy of wastewater treatment, so it is appropriate to take DO control as an example [109]. 
High-intensity aeration is needed to maintain DO at $2-4 \mathrm{mg} / \mathrm{L}$ to maintain good microbial activity and nitrification performance in the activated sludge process. Inadequate $\mathrm{DO}$ will lead to the inactivity of microorganisms and affect the treatment process. However, excessive DO will deteriorate the sludge quality, makes the denitrification less efficient and leads to waste of energy [113]. DO control is realized by adjusting the air volume of the centrifuge.

Proportion Integration Differentiation (PID) control, a closed-loop automatic control technology based on the feedback concept, is the main control method for DO in the past decades. However, DO control has non-linearity and time-delay, which make traditional PID control is difficult to meet the increasingly stringent control requirements $[108,109]$. Some studies show that it is difficult to improve the accuracy of wastewater treatment processes control by using PI and PID [114].

Advanced control algorithms such as Model Predictive Control (MPC), Neural Network and Fuzzy Logic have gradually become the mainstream in DO control, and they have achieved some results in practical applications which are shown in table 5 [108-111]. Fuzzy logic and MPC are the most commonly used advanced algorithms in DO control. MPC, a class of algorithms that using a system model to calculate a series of manipulation variables to optimize future behavior, is another method that can overcome the uncertainty and nonlinearity in this filed [107,113]. However, it is difficult for MPC to identify many time-varying parameters to establish a reasonable prediction model. Fuzzy control does not require an accurate mathematical model of the controlled system but can incorporate fuzzy rules directly into the controllers to guarantee the global stability of the system, which is a good method for controlling these ill-defined, time-varying and non-linear systems $[115,116]$. However, the establishment of a fuzzy control rule base is semi-empirical, and there are some difficulties in practical application [117].

\subsection{Measurement and Implementation}

The measurement system is mainly composed of sensors and online instruments and is a module for data measurement and input. The development of sensors, instruments, and communication systems enables real-time data collection from the entire system [118]. The measurement and implementation of WWTPs depend on the development of instrumentation, control, and automation (ICA) $[119,120]$. The purposes of using ICA are to keep treatment systems running efficiently in the presence of large fluctuations and to achieve the desired performance at an affordable cost. Studies show that the nutrient removal rate of wastewater can be increased by $10-30 \%$ by using ICA technology in WWTPs [121]. With improvement of ICA, smart sensors with multiple detectors and transmission abilities will be widely used [122]. Sensors and monitoring systems are used to collect and transmit data, provide early warning and analysis data, and provide information to managers, which helps managers operate, control and make decisions $[123,124]$.

The implementation system corrects the action of the system according to the process control algorithm to achieve the desired change when the controller monitors the state of a system. This kind of execution is usually realized by feedback and feedforward. Ireland's Ringsend WWTP uses a variable frequency driver to change the speed of the pump to match the flow conditions, reducing the energy consumption of the pump by up to 50\% [125]. Upgrading of the equipment itself can also bring about a reduction in energy consumption. It is easy to save more than $35 \%$ energy by replacing the traditional blower technology with the direct drive turbine blower [126]. Wastewater pumps operational life ranges between 15 and 20 years. However, they are not directly addressed in "Waste electrical and electronic equipment" Directive (2012/19/EU). Therefore, wastewater pumps have the possibility of renovation or upgrading. The research of Psomopoulos et al. shows that sewage pump has high recovery potential, which may bring huge environmental and economic benefits [127]. Therefore, upgrading the sewage pump can improve energy efficiency without worrying about the disposal of the equipment. Although the European Commission's previous standards for wastewater pumps focused on energy efficiency, many recent studies have focused on reliability and delivery characteristics [128]. 


\subsection{Control Strategy and Decision-Making}

Choosing the appropriate decision-making factors is the premise of formulating control strategies. Different objectives will lead to completely different optimization results. Sweetapple et al. used NSGA-II, a multi-objective evolutionary algorithm, to study the potential of control strategy optimization for the reduction of greenhouse gas (GHG) emissions from wastewater treatment in a cost-effective manner [129]. They took GHG emissions, effluent quality and operational costs as trade-off objectives and found that water quality standards and GHG emissions are negatively correlated, while energy consumption does not have a significant impact on GHG emissions. Other researchers have used multi-objective optimization methods, such as genetic algorithms and particle swarm, to draw similar conclusions [130-132]. Flores-Alsina et al. proposed some suggestions to improve wastewater discharge standards with low greenhouse gas emissions by using multi-objective optimization [133]. Hreiz et al. used multi-objective optimization techniques to balance processing costs and efficiency [134]. The wastewater treatment process which has obvious non-linearity and multi-objective optimization can help to make rational decisions and balance multiple objectives, such as effluent quality, energy consumption, operation cost, GHG emissions. Therefore, studying intelligent multi-objective optimization control technology for urban wastewater treatment is still an important research direction in the current wastewater treatment industry [132,135]. It is worth noting that policies have direct impacts on the optimization objectives. For the EU, energy efficiency is not the only focus of attention, according to EU Urban Wastewater Treatment Directive (91/271) [21,136]. Moreover, tax, cost, environmental impact, and other factors are the goals that need to be concerned.

Modeling and simulation is a good technique to evaluate the condition of process control in WWTPs by providing reference data, which can help researchers to facilitate a control strategy development, make a decision and evaluate performance [137]. Activated Sludge Models (ASMs) released by International Water Association (IWA), have great significance in process design and simulation verification, which can show the working mechanism of the treatment process. The ASM1 includes the basic biotransformation processes of an activated sludge WWTP which is used to describe the denitrification process in a WWTP [138]. BSM1, which includes a simulation model, a control strategy, evaluation standards, and test procedures, is useful in testing control strategies [103,139]. Many researchers use the modified model to save energy, reduce cost, and evaluate control strategies $[137,140,141]$. Jeppsson et al. made an extension of BSM1 to facilitate a control strategy development and performance evaluation [142]. Kim et al. optimized the modified anaerobic, buffer, intermittently aerated, and oxic $\left(\mathrm{ABA}^{2}\right)$ process with linearized ASM2 for saving aeration energy [143].

\section{Performance Evaluation of Energy Conservation Technologies and WWTPs}

Before introducing the evaluation methods and indicators, we use a table to summarize the main energy-saving technologies mentioned in this paper. These technologies include green energy technologies and optimization technologies, it is difficult to evaluate them with a unified indicator, so we will explain them in the form of cases. Table 6 shows some common energy-saving technologies and their energy efficiency performance.

Many factors, such as processes, scale, water quality, have a great impact on energy consumption, which has been explained in Section 1.2.2. This review introduces a variety of energy-saving technologies from the aspects of energy supply and system optimization in Sections 2 and 3. Therefore, some indexes and methods are needed to evaluate the application value and comprehensive performance of these energy conservation technologies. 
Table 6. Energy consumption of WWTPs using common green energy technologies.

\begin{tabular}{cccc}
\hline Types & Technologies & Achievements & Reference \\
\hline Solar energy & PV power generation & Provide 10\% energy needs & {$[144]$} \\
\hline Heat energy & Wastewater source heat pump & Electricity equivalent 2.18 kWh/m & {$[144]$} \\
\hline \multirow{2}{*}{ Biomass energy } & Anaerobic digestion & Provide 50\% energy needs & {$[144]$} \\
& Microbial fuel cell & Achieve 0.360 kWh/kg COD & {$[145]$} \\
\hline \multirow{2}{*}{ Chemical energy } & Pyrolysis & Recover 59.2-79.3\% sludge energy & {$[146]$} \\
& Incineration & Provide 20\% energy needs & {$[62]$} \\
\hline \multirow{2}{*}{ Algorithms } & Fuzzy algorithm & Save about 40\% of the energy & {$[111]$} \\
& Model Predictive Control & Reduce over 25\% in power usage & {$[147]$} \\
\hline \multirow{2}{*}{ Equipment } & Use the direct drive turbine & Save more than 35\% energy & {$[125]$} \\
& Use variable frequency driver & Reducing energy consumption by up to 50\% & {$[126]$} \\
\hline Control strategy & ASM2d model & Save 2.2 to 3.3\% of energy & {$[148]$} \\
\hline
\end{tabular}

\subsection{Evaluation Indexes}

The appropriate evaluation index can not only evaluate energy the performance of WWTPs horizontally but also evaluates the differences of processes vertically, which can provide guidance for technological improvement. Besides, it can help researchers confirm the application value of energy conservation technologies [149]. The diversity of energy-saving technologies makes some indexes that can comprehensively compare their differences more valuable. In Section 1.2.1, EI is used to describe energy performance. Energy consumption per volume of treated wastewater and energy consumption per unit of pollutant removal are two widely used energy indexes, both of which have some problems [150]. Energy consumption per unit of pollutant removal needs to consider a variety of pollutants, which will cause difficulties, while energy consumption per volume of treated wastewater ignores the difference of wastewater (water quality, scale, process, etc.). This problem has been described in Section 1.2.1. The premise of using energy consumption per volume of treated wastewater is that the fluctuation of influent water quantity and water quality (COD, BOD, SS, TN, and $\mathrm{TP}$, etc.) of sewage treatment plants is relatively small, and the situation of influent water quality and water quantity of each sewage treatment plant is comparatively close. In general, energy conservation technology needs to consider energy, feasibility, treatment capacity, economy, environment, policy, water supply safety, risk, and other factors. This is also the premise of energy-saving applications such as multi-objective optimization and optimal control.

There are various performance evaluation indexes for WWTPs. Table 7 shows the indexes used by some researchers. These different indexes with different concerns can show the various situations of WWTPs. This makes the data on energy performance, application value and popularization potential of energy-saving technology more reliable.

Table 7. Evaluation indexes adopted by different researchers.

\begin{tabular}{|c|c|c|}
\hline Objectives & Indexes & Reference \\
\hline Water quality & Total oxygen demand, Oxygen consumption potential, EO index & [151] \\
\hline Economy & $\begin{array}{l}\text { Energy use per unit emission reduction, Cost per unit emission } \\
\text { reduction, Environmental benefit per unit investment, Ratio of energy } \\
\text { consumption from sewage treatment to national total energy } \\
\text { consumption, Ratio of cost of sewage treatment to the Gross Domestic } \\
\text { Product, Structural Coordination degree of sewage treatment, and Scale } \\
\text { harmony degree of sewage treatment, Financial payback time }\end{array}$ & {$[152,153]$} \\
\hline $\begin{array}{l}\text { Wastewater recovery \& } \\
\text { utilization }\end{array}$ & $\begin{array}{l}\text { Wastewater Circonomics Index, Waste Production Efficiency Indicator, } \\
\text { Composite Wastewater Reuse indicator, Wastewater recycling indicator }\end{array}$ & [154] \\
\hline Energy & $\begin{array}{l}\text { Material flow, Energy flow, Specific energy consumption, Chemical } \\
\text { energy potential, Biochemical energy potential }\end{array}$ & [155] \\
\hline
\end{tabular}


Table 7. Cont.

\begin{tabular}{cccc}
\hline Objectives & Indexes & Reference \\
\hline Environment & $\begin{array}{c}\text { Risk quotient, Quantitative microbial risk assessment, Changes in } \\
\text { ecosystem distribution, Soil productivity and permeability }\end{array}$ & $\begin{array}{c}\text { Probability of a threat, Material losses, Human losses, security category, } \\
\text { Four-Parameter risk matrix }\end{array}$ \\
\hline Water supply safety & $\begin{array}{c}\text { Removal efficiency, Toxic Units } \\
\text { Treatment capacity }\end{array}$ & $\begin{array}{c}\text { Process advancement, Process maturity, Process stability, Construction } \\
\text { costs, Operating costs, Floor area, Operations' personnel, Facility } \\
\text { operations, Dependence on the downstream environment, Dependence } \\
\text { on the upstream environment }\end{array}$ \\
\hline [160]
\end{tabular}

However, many researchers pay attention to a unit but do not set indexes from the whole life cycle, which makes indexes not comprehensive. It is not a good choice, because the indexes have a great impact on the audit results of WWTPs [149]. To establish a unified analysis method for energy consumption in WWTPs, the ENERWATER project was launched in Europe to conduct index studies on WWTPs. Water treatment energy index (WTEI), a comprehensive index formed by weighting and a combination of multiple indexes, is used to evaluate the energy efficiency of WWTPs in the ENERWATER framework [162]. After confirming the type of WWTP, indexes are constructed according to the data of energy consumption, pollutant concentration, and flow rate.

\subsection{Evaluation Methods}

Appropriate evaluation methods can help managers to understand the energy utilization of the entire process through various data of the wastewater treatment plant, and to find opportunities for energy efficiency optimization. Only when the above objectives are achieved, can the results of energy research and technical analysis be used to guide technological transformation and engineering practice. Stefano Longo et al. study three benchmark methods: normative method, statistical method, and programming method, and conducted energy efficiency evaluation [150].

The Key Performance Indicators (KPIs) method is the most common and simplest evaluation method. KPIs, the most commonly used evaluation method in WWTPs, is usually expressed as the ratio of output to input. The KPIs method is simple and easy to implement, but it can only evaluate specific parts, and it cannot systematically evaluate the status of WWTPs [16,150]. Although the KPIs can be created by weighting, the complexity of the WWTPs process makes the method unsuitable [162]. Similarly, the KPIs method ignores the differences in WWTPs (location, size, process).

Data Envelopment Analysis (DEA) is a tool using mathematical programming technology for performance evaluation. It can be used to evaluate energy performance in complex systems such as wastewater treatment because it can deal with multiple inputs and outputs problems [163-165]. The BCC model and the CCR ratio model are two types of DEA models [166]. The CCR model can evaluate the overall efficiency of a unit while the BCC model evaluates the pure technical efficiency of a unit. Guerrini et al. used DEA to study the relationship between sewage characteristics and energy efficiency [167]. They gave some suggestions for efficient operation.

Statistical methods such as ordinary least squares (OLS) and stochastic frontier analysis (SFA) are commonly used evaluation methods. These methods are mainly used to explore the influence of factors on energy efficiency and identify its determinants [162]. These methods regard the difference between the reference value and the actual value as a measure of efficiency. OLS uses the fitted regression line to express evaluation efficiency. In the OLS method, all treatment plants with below-average ratings are considered efficient [168]. SFA, which needs to determine the specific form of the production frontier, is a method of frontier analysis. Its advantage is to consider the impact of random factors on the results. 
SFA separates inefficient components from incorrect components to make efficiency measurements more accurate, which is significant in the energy efficiency analysis of wastewater treatment [150].

Life Cycle Assessment (LCA) is an important framework in the evaluation process. LCA involves the whole process of a product life cycle, including the input of energy and raw materials, the output of wastewater, waste gas and solid waste, etc. LCA is an important tool for wastewater treatment assessment, which can be used to evaluate energy utilization and pollutant discharge $[169,170]$. Santoyo-Castelazo et al. constructed frameworks including scenario analysis, LCA, life cycle cost calculation, social sustainability assessment, and multi-criteria decision analysis to assess and identify the most sustainable energy options, and to develop decision support frameworks for the comprehensive assessment of energy system sustainability considering environmental, economic and social aspects [171]. Lorenzo-Toja et al. have proved that the combination of LCA and DEA can be a valuable method for evaluating performance of WWTPs [172]. Massoud et al. evaluate and select appropriate wastewater treatment technology with LCA, considering the cost of design, construction, operation, maintenance, repair and replacement [173].

\section{Challenges and Perspectives for Water and Energy Nexus}

Besides the energy consumption problem, there are many challenges in the wastewater treatment industry. Only by finding problems can we solve them better. In the previous section, the application and evaluation of some energy-saving technologies are introduced, most of which have matured or developed at a high speed. However, there are still some new directions for energy-saving technology of wastewater treatment.

\subsection{Challenges}

However, with the rapid development of wastewater treatment, some problems and challenges are gradually exposed. These challenges can be roughly divided into cost issues, technology issues, management issues, and external issues $[18,47,174]$. These issues are often intertwined with each other.

The expansion of the city and the development of industry make the existing WWTPs and pipe networks difficult to meet the requirements. In developing countries, the wastewater treatment capacity cannot fit the wastewater discharge volume. The gaps is still further expanding, which makes the problem fiercer [173]. Wastewater treatment facilities have a high investment and account for a large proportion of the national economy. In the 1980s, the investment in wastewater treatment of China, the United States, Japan, Germany, and France respectively accounted for $0.02-0.034 \%, 0.80 \%$, $0.75 \%, 0.88 \%$, and $0.53 \%$ of the gross national product (GNP) [175]. Similarly, the operation of WWTPs requires a lot of money. The cost of construction and operation has become a bottleneck restricting the development of the wastewater treatment industry [19]. Considering the conflict between the large gap of wastewater treatment and the high cost of construction, a feasible scheme is to adopt a suitable wastewater management mode. Distributed wastewater management is an important solution for developing countries [176]. Some studies have shown that the rational allocation of infrastructure can minimize costs $[177,178]$. However, this work needs a lot of data to support. Similarly, wastewater treatment cost forecasting has important values in reducing costs. Accurate forecasting can help the government to make reasonable plans [27].

The core of technological challenges is the high energy consumption. To meet the increasing water quality requirements, municipal WWTPs should increase aeration volume, prolong aeration time and increase sludge return flow, which leads to the increase of energy consumption. Sludge disposal and resource utilization have not received enough attention. The vast majority of sludge is simply landfilled and incinerated, which can also cause serious environmental pollution. At present, less than $10 \%$ of WWTPs in the United States are producing surplus biogas for commercial use [41,47]. Advanced wastewater treatment technologies are not widely used in WWTPs. This may be due to technical barriers or high upgrade costs. Reducing GHG emissions is also a major technical challenge 
to WWTPs [39,133]. To reduce GHG emissions, monitoring, model, emission reduction technology, cleaner production, and other technologies need to be paid enough attention $[129,132,179,180]$.

For the wastewater treatment industry, external challenges mainly come from the change of pollutants. The emergence of new pollutants, such as micro plastics, hormone, and medicine, has brought external challenges to the wastewater treatment industry [181,182]. Mutiyar believes that antibiotics as an important water pollutant have not received enough attention in India [183]. Wastewater treatment plants usually do not deal with pollutants occurring in the sub-mg/L, which makes micro pollutants accumulate in drinking water and pose a threat to human health. Therefore, the monitoring and treatment of micro pollutants in key water bodies must be paid enough attention, which is a technical and managerial challenge [184].

\subsection{Perspectives}

With the rapid development of energy-saving technology in wastewater treatment, many new technologies have attracted the attention of researchers.

Internet of Things (IoT) is an extension and expansion of the Internet, combining various information sensing devices with the Internet to form a huge network. It can realize the interconnection of people, machines and things. Low-cost sensors and low-power wireless telecommunication are the core of IoT for information acquisition and interaction. Compared with traditional sensors, sensors of IoT have lower costs and can be installed at higher densities, making it gather more data [102]. Intelligent sensors are installed in different locations of WWTPs to collect data on water quality, temperature, pressure, water, and chemical leakage, and transmit these data to data center through the Internet. By using these data, WWTPs can track wastewater flow, monitor wastewater leakage, monitor bacterial and microbial distribution, and achieve other functions [58]. A Spain WWTP using IoT has achieved a great performance. The production of sludge dropped by $17 \%$ and the use of chemicals for P removal dropped 14\%, while the electricity consumption dropped by $13.5 \%$ [185].

In terms of energy recovery of sludge, pretreatment technology has also attracted the attention of some researchers [57]. Ariunbaatar et al. compared the main pretreatment technologies, such as mechanical, thermal, chemical and biological methods from the perspectives of efficiency, energy balance, cost and process sustainability [186]. Pretreatment methods can recover more energy in $\mathrm{AD}$, reduce the cost of sterilization, and accelerate hydrolysis $[187,188]$. Through pretreatments, the concentration and amount of $\mathrm{CH}_{4}$ produced by AD have been greatly increased [186,189]. Heat treatment is the most commonly used pretreatment and has been applied in the industry [190,191]. However, pretreatments also require energy consumption and treatment costs, which should be taken into consideration. Only by utilizing the produced biogas and other products can the technology be feasible in practice [189].

Compared with a single energy-saving technology, energy self-sufficiency technology has become a research hotspot and future development direction [45,46]. Energy self-sufficiency is a more systematic energy-saving framework, including green energy, system optimization, industrial design, and other aspects. Nowak et al. investigated two WWTPs in Austria and found that nutrient removal and aerobic sludge digestion can achieve energy self-sufficiency [192]. This is mainly achieved through the optimization of the control system and the application of green energy. In fact, the two points described in Sections 2 and 3 are applicable to all WWTPs that want to reduce energy consumption and achieve energy self-sufficiency [18]. Jenicek et al. maintained that most WWTPs can achieve or close to self-sufficiency by upgrading energy recovery technologies such as AD [46].

\section{Conclusions}

Energy consumption is an important problem for WTTPs and related industries. So reducing energy consumption is the main trend of future development. This review introduces the scheme of saving energy consumption from three angles. Several examples of energy-self-sufficient WWTPs have 
proved that green energy technologies (especially energy recovery technologies), system optimization and control technologies, and performance evaluation will benefit energy-saving.

Compared with solar energy, hydropower, and other green energy sources, energy recovery from sewage sludge has lower cost and better feasibility. System optimization and control can improve the energy efficiency of wastewater treatment and enhance the level of automation. More attention should be paid to the control of operation processes because it asks a lower upgrade cost compared with other energy-saving technologies. The evaluation indexes and methods should be comprehensive and take the whole life cycle into consideration, such as the ENERWATER framework. The establishment of the evaluation system is a systematic project that needs collaboration. It still takes time to improve the system.

Although some challenges, such as cost issues, technology issues, management issues, and external issues, have temporarily affected the industry, they also point out the direction for future research. IoT, pretreatment, energy self-sufficiency and other emerging technologies have brought new solutions to the high energy consumption of wastewater treatment.

Author Contributions: Conceptualization, Y.S. (Yongteng Sun) and Y.S. (Yongjun Sun); Data curation, Z.C., H.D., and D.L.; Formal analysis, Y.S. (Yongteng Sun) and Y.S. (Yongjun Sun); Funding acquisition, M.L.; Supervision, M.L. and Y.S. (Yongjun Sun); Writing-original draft, Y.S. (Yongteng Sun); Writing-review and editing, Y.S. (Yongteng Sun) and Y.S. (Yongjun Sun).

Funding: This research was funded by the National Natural Science Foundation of China, grant number 61672226.

Conflicts of Interest: The authors declare no conflict of interest.

\section{Abbreviations}

The following abbreviations are used in this manuscript:

$\begin{array}{ll}\text { WWTP } & \text { Wastewater Treatment Plants } \\ \text { WW\&S } & \text { Wastewater and sludge } \\ \text { BOD } & \text { Biochemical oxygen demand } \\ \text { COD } & \text { Chemical oxygen demand } \\ \text { SS } & \text { Suspended solids } \\ \text { EI } & \text { Energy intensity } \\ \text { SBR } & \text { Sequencing batch reactor } \\ \text { AOPs } & \text { Advanced oxidation processes } \\ \text { WWSHP } & \text { Wastewater source heat pump } \\ \text { AD } & \text { Anaerobic digestion } \\ \text { MFC } & \text { Microbial fuel cell } \\ \text { PID } & \text { Proportion integration differentiation } \\ \text { MPC } & \text { Model Predictive Control } \\ \text { DO } & \text { Dissolved oxygen } \\ \text { ICA } & \text { Instrumentation, control and automation } \\ \text { GHG } & \text { Greenhouse gas } \\ \text { ASM } & \text { Activated Sludge Model } \\ \text { BSM } & \text { Benchmark Simulation Model } \\ \text { KPIs } & \text { Key Performance Indicators } \\ \text { DEA } & \text { Data Envelopment Analysis } \\ \text { BCC } & \text { Model introduced by Banker, Charnes and Cooper } \\ \text { CCR } & \text { Model introduced by Charnes, Cooper and Rhodes } \\ \text { OLS } & \text { Ordinary Least Aquares } \\ \text { SFA } & \text { Stochastic Frontier Analysis } \\ \text { LCA } & \text { Life Cycle Assessment } \\ \text { IoT } & \text { Internet of Things } \\ & \end{array}$

\section{References}

1. Vörösmarty, C.J.; McIntyre, P.B.; Vörösmarty, C.J.; McIntyre, P.B.; Gessner, M.O.; Dudgeon, D.; Prusevich, A.; Green, P.; Glidden, S.; Bunn, S.E.; et al. Global threats to human water security and river biodiversity. Nature 2010, 467, 555. 
2. Sun, Y.; Chen, Z.; Wu, G.X.; Wu, Q.Y.; Zhang, F.; Niu, Z.B.; Hu, H.Y. Characteristics of water quality of municipal wastewater treatment plants in China: Implications for resources utilization and management. J. Cleaner Prod. 2016, 131, 1-9. [CrossRef]

3. Jager, N.; Challies, E.; Kochskämper, E.; Newig, J.; Benson, D.; Blackstock, K.; Collins, K.; Evers, M.; Feichtinger, J.; Fritsch, O.; et al. Transforming European water governance? Participation and river basin management under the EU Water Framework Directive in 13 member states. Water 2016, 8, 156. [CrossRef]

4. Guan, X.H.; Chen, G.H.; Shang, C. Re-use of water treatment works sludge to enhance particulate pollutant removal from sewage. Water Res. 2005, 39, 3433-3440. [CrossRef] [PubMed]

5. Metcalf, E. Wastewater Engineering: Treatment and Reuse, 4th ed.; McGraw-Hill: New York, NY, USA, 2003.

6. Appels, L.; Baeyen, J.; Degrève, J.; Dewil, R. Principles and potential of the anaerobic digestion of waste-activated sludge. Prog. Energy Combust. Sci. 2008, 34, 755-781. [CrossRef]

7. Qasim, S.R. Wastewater Treatment Plants: Planning Design and Operation, 2nd ed.; CRC Press: Boca Raton, FL, USA, 1999.

8. Gupta, V.K.; Ali, I.; Saleh, T.A.; Nayak, A.; Agarwal, S. Chemical treatment technologies for waste-water recycling-an overview. RSC Adv. 2012, 2, 6380-6388. [CrossRef]

9. Ning, P.; Bart, H.; Jiang, Y.; De, H.A.; Tien, C. Treatment of organic pollutants in coke plant wastewater by the method of ultrasonic irradiation, catalytic oxidation and activated sludge. Sep. Purif. Technol. 2015, 41, 133-139. [CrossRef]

10. Boujelben, I.; Samet, Y.; Messaoud, M.; Makhlouf, M.B.; Maalej, S. Descriptive and multivariate analyses of four Tunisian wastewater treatment plants: A comparison between different treatment processes and their efficiency improvement. J. Environ. Manag. 2017, 187, 63-70. [CrossRef]

11. Venkatesh, G.; Brattebø, H. Energy consumption, costs and environmental impacts for urban water cycle services: Case study of Oslo (Norway). Energy 2011, 36, 792-800. [CrossRef]

12. Singh, P.; Kansal, A. Energy and GHG accounting for wastewater infrastructure. Resour. Conserv. Recycl. 2018, 128, 499-507. [CrossRef]

13. Niu, K.; Wu, J.; Qi, L.; Niu, Q. Energy intensity of wastewater treatment plants and influencing factors in China. Sci. Total Environ. 2019, 670, 961-970. [CrossRef] [PubMed]

14. Panepinto, D.; Fiore, S.; Zappone, M.; Genon, G.; Meucci, L. Evaluation of the energy efficiency of a large wastewater treatment plant in Italy. Appl. Energy 2016, 161, 404-411. [CrossRef]

15. Torregrossa, D.; Hansen, J.; Hernández-Sancho, F.; Cornelissen, A.; Schutz, G.; Leopold, U. A data-driven methodology to support pump performance analysis and energy efficiency optimization in Waste Water Treatment Plants. Appl. Energy 2017, 208, 1430-1440. [CrossRef]

16. Torregrossa, D.; Schutz, G.; Cornelissen, A.; Hernández-Sancho, F.; Hansen, J. Energy saving in WWTP: Daily benchmarking under uncertainty and data availability limitations. Environ. Res. 2016, 148, 330-337. [CrossRef]

17. Gude, V.G. Energy and water autarky of wastewater treatment and power generation systems. Renew. Sustain. Eneregy Rev. 2015, 45, 52-68. [CrossRef]

18. Gu, Y.; Li, Y.; Li, X.; Luo, P.; Wang, H.; Robinson, Z.P.; Wang, X.; Wu, J.; Li, F. The feasibility and challenges of energy self-sufficient wastewater treatment plants. Appl. Energy 2017, 204, 1463-1475. [CrossRef]

19. Wang, H.T.; Yang, Y.; Keller, A.A.; Li, X.; Feng, S.; Dong, Y.N.; Li, F. Comparative analysis of energy intensity and carbon emissions in wastewater treatment in USA, Germany, China and South Africa. Appl. Energy 2016, 184, 873-881. [CrossRef]

20. Hernández-Sancho, F.; Molinos-Senante, M.; Sala-Garrido, R. Energy efficiency in Spanish wastewater treatment plants: A non-radial DEA approach. Sci. Total. Environ. 2011, 409, 2693-2699. [CrossRef]

21. Avilés, A.B.L.; Velázquez, F.D.C.; Riquelme, M.P.D. Methodology for energy optimization in wastewater treatment plants. Phase I: Control of the best operating conditions. Sustainability 2019, 11, 3919. [CrossRef]

22. King, C.W.; Holman, A.S.; Webber, M.E. Thirst for energy. Nat. Geosci. 2008, 1, 283. [CrossRef]

23. Means, E., III (Ed.) Water and Wastewater Industry Energy Efficiency: A Research Roadmap; Awwa Research Foundation: Denver, CO, USA, 2004; pp. 28-29.

24. Molinos-Senante, M.; Sala-Garrido, R.; Iftimi, A. Energy intensity modeling for wastewater treatment technologies. Sci. Total Environ. 2018, 630, 1565-1572. [CrossRef] [PubMed]

25. Alidrisi, H. Developing an input-oriented data envelopment model for wastewater treatment plants. Life Sci. J. 2014, 11, 875-879. 
26. Zhang, Z.; Chang, X.; Chen, A. Determination of chemical oxygen demand based on photoelectrocatalysis of nanoporous $\mathrm{TiO}_{2}$ electrodes. Sens. Actuators B Chem. 2016, 223, 664-670. [CrossRef]

27. Wang, Y.; Wu, L.; Engel, B. Prediction of sewage treatment cost in rural regions with multivariate adaptive regression splines. Water 2019, 11, 195. [CrossRef]

28. He, Y.; Zhu, Y.; Chen, J.; Huang, M.; Wang, P.; Wang, G.; Zou, W.; Zhou, G. Assessment of energy consumption of municipal wastewater treatment plants in China. J. Cleaner Prod. 2019, 228, 399-404. [CrossRef]

29. Tao, X.; Chengwen, W. Energy Consumption in Wastewater Treatment Plants in China. In Proceedings of the World Congress on Water, Climate and Energy, Dublin, Ireland, 13-18 May 2012; pp. 1-6.

30. Global Water Research Coalition (GWRC). An Energy and Carbon Footprint Neutral Urban Water Cycle by 2030 Workshop on Water and Energy; GWRC: Unley, Australia, 2011.

31. Udaeta, M.E.M.; Medeiros, G.A.S.; da Silva, V.O.; Galvão, L.C. Basic and procedural requirements for energy potential from biogas of sewage treatment plants. J. Environ. Manag. 2019, 236, 380-387. [CrossRef]

32. Yang, L.; Zeng, S.; Chen, J.; He, M.; Yang, W.O. Operational energy performance assessment system of municipal wastewater treatment plants. Water Sci. Technol. 2010, 62, 1361-1370. [CrossRef]

33. Xu, J.; Luo, P.Z.; Lu, B.; Wang, H.; Wang, X.; Wu, J.; Yan, J. Energy-water nexus analysis of wastewater treatment plants (WWTPs) in China based on statistical methodologies. Energy Procedia 2018, 152, $259-264$. [CrossRef]

34. Jiang, Y.; Fu, W.; Mao, L.H.; Ren, F.M.; Yang, L.; Xiang, J.; Liang, R.; Hao, H.M.; Wang, Z. Influence factors analysis of urban sewage treatment plant on energy consumption. J. Bejing Jiaotong Univ. 2014, 38, $33-37$.

35. Nowak, O.; Enderle, P.; Varbanov, P. Ways to optimize the energy balance of municipal wastewater systems: Lessons learned from Austrian applications. J. Clean. Prod. 2015, 88, 125-131. [CrossRef]

36. Gurung, K.; Tang, W.Z.; Sillanpää, M. Unit energy consumption as benchmark to select energy positive retrofitting strategies for Finnish wastewater treatment plants (WWTPs): A case study of Mikkeli WWTP. Environ. Process. 2018, 5, 667-681. [CrossRef]

37. McCarty, P.L.; Bae, J.; Kim, J. Domestic wastewater treatment as a net energy producer-Can this be achieved? Environ. Sci. Technol. 2011, 45, 7100-7106. [CrossRef] [PubMed]

38. Singh, R.; Gupta, S.; Raman, S.; Chakraborty, P.; Sharma, P.; Sharma, R.K.; Brown, L.C.; Wei, X.; Plappally, A. Comparative analysis of hydrodynamics of treatment wetlands using finite volume models with empirical data. Desalin. Water Treat. 2015, 55, 3587-3612. [CrossRef]

39. Mizuta, K.; Shimada, M. Benchmarking energy consumption in municipal wastewater treatment plants in Japan. Water Sci. Technol. 2010, 62, 2256-2262. [CrossRef]

40. Bodik, I.; Kubaska, M. Energy and sustainability of operation of a stewater treatment plant. Environ. Prot. Eng. 2013, 39, 15-24.

41. Castellet-Viciano, L.; Hernández-Chover, V.; Hernández-Sancho, F. Modelling the energy costs of the wastewater treatment process: The influence of the aging factor. Sci. Total Environ. 2018, 625, 363-372. [CrossRef]

42. Longo, S.; Hospido, A.; Lema, J.M.; Mauricio-Iglesias, M. A systematic methodology for the robust quantification of energy efficiency at wastewater treatment plants featuring Data Envelopment Analysis. Water Res. 2018, 141, 317-328. [CrossRef]

43. Mamais, D.; Noutsopoulos, C.; Dimopoulou, A.; Stasinakis, A.; Lekkas, T.D. Wastewater treatment process impact on energy savings and greenhouse gas emissions. Water Sci Technol. 2015, 71, 303-308. [CrossRef]

44. Chae, K.J.; Kang, J. Estimating the energy independence of a municipal wastewater treatment plant incorporating green energy resources. Energy Convers. Manag. 2013, 75, 664-672. [CrossRef]

45. Jenicek, P.; Bartacek, J.; Kutil, J.; Zabranska, J.; Dohanyos, M. Potentials and limits of anaerobic digestion of sewage sludge: Energy self-sufficient municipal wastewater treatment plant? Water Sci. Technol. 2012, 66, 1277-1281. [CrossRef]

46. Jenicek, P.; Kutil, J.; Benes, O.; Todt, V.; Zabranska, J.; Dohanyos, M. Energy self-sufficient sewage wastewater treatment plants: Is optimized anaerobic sludge digestion the key? Water Sci. Technol. 2013, 68, 1739-1744. [CrossRef] [PubMed]

47. Shen, Y.; Linville, J.L.; Urgun-Demirtas, M.; Mintz, M.M.; Snyder, S.W. An overview of biogas production and utilization at full-scale wastewater treatment plants (WWTPs) in the United States: Challenges and opportunities towards energy-neutral WWTPs. Renew. Sustain. Eneregy Rev. 2015, 50, 346-362. [CrossRef] 
48. Frijns, J.; Hofman, J.; Nederlof, M. The potential of (waste)water as energy carrier. Energy Convers. Manag. 2013, 65, 357-363. [CrossRef]

49. Close, J.; Ip, J.; Lam, K.H. Water recycling with PV-powered UV-LED disinfection. Renew. Energy 2006, 31 , 1657-1664. [CrossRef]

50. Drouiche, N.; Djouadi-Belkada, F.; Ouslimane, T.; Kefaifi, A.; Fathi, J.; Ahmetovic, E. Photovoltaic solar cells industry wastewater treatment. Desalin. Water Treat. 2013, 51, 1657-1664. [CrossRef]

51. Antoniadis, A.; Takavakoglou, V.; Zalidis, G.; Poulios, I. Development and evaluation of an alternative method for municipal wastewater treatment using homogeneous photocatalysis and constructed wetlands. Catal. Today 2007, 124, 260-265. [CrossRef]

52. Deng, Y.; Zhao, R. Advanced oxidation processes (AOPs) in wastewater treatment. Curr. Pollut. Rep. 2015, 1, 167-176. [CrossRef]

53. Miralles-Cuevas, S.; Oller, I.; Pérez, J.S.; Malato, S. Removal of pharmaceuticals from MWTP effluent by nanofiltration and solar photo-Fenton using two different iron complexes at neutral pH. Water Res. 2014, 61, 23-31. [CrossRef]

54. Fendrich, M.A.; Quaranta, A.; Orlandi, M.; Bettonte, M.; Miotello, A. Solar concentration for wastewaters remediation: A review of materials and technologies. Appl. Sci. 2019, 9, 118. [CrossRef]

55. Munoza, I.; Rieradevalla, J.; Torrades, F.; Peral, J.; Domènech, X. Environmental assessment of different solar driven advanced oxidation processes. Sol. Energy 2005, 79, 369-375. [CrossRef]

56. Nisan, S.; Commercon, B.; Dardour, S. A new method for the treatment of the reverse osmosis process, with preheating of the feedwater. Desalination 2005, 182, 483-495. [CrossRef]

57. Wacławek, S.; Grübel, K.; Silvestri, D.; Padil, V.V.; Wacławek, M.; Černík, M.; Varma, R.S. Disintegration of wastewater activated sludge (WAS) for improved biogas production. Energies 2019, 12, 21. [CrossRef]

58. Guo, Z.; Sun, Y.J.; Pan, S.Y.; Chiang, P.C. Integration of green energy and advanced energy-efficient technologies for municipal wastewater treatment plants. Int. J. Environ. Res. Public Health 2019, 16, 1282. [CrossRef] [PubMed]

59. Colburn, A.S.; Meeks, N.; Weinman, S.T.; Bhattacharyya, D. High total dissolved solids water treatment by charged nanofiltration membranes relating to power plant applications. Ind. Eng. Chem. Res. 2016, 55, 4089-4097. [CrossRef] [PubMed]

60. Wu, H.; Chen, B.; Guo, C. Capacity optimization of hybrid energy storage units in wind/solar generation system. Source Trans. Chin. Soc. Agric. Eng. 2011, 27, 241-245.

61. Xu, L.; Ruan, X.; Mao, C.; Zhang, B.; Luo, Y. An Improved Optimal Sizing Method for Wind-Solar-Battery Hybrid Power System. IEEE Trans. Sustain. Energy 2016, 4, 774-785.

62. Tyagi, V.K.; Lo, S.L. Sludge: A waste or renewable source for energy and resources recovery? Renew. Sustain. Eneregy Rev. 2013, 25, 708-728. [CrossRef]

63. Fontoulakis, M.S.; Drakopoulou, S.; Terzakis, S.; Georgaki, E.; Manios, T. Potential for methane production from typical Mediterranean agro-industrial by-products. Biomass Bioenergy 2008, 32, 155-161. [CrossRef]

64. Calabro, P.S.; Folino, A.; Tamburino, V.; Zappia, G.; Zema, D.A. Increasing the tolerance to polyphenols of the anaerobic digestion of olive wastewater through microbial adaptation. Biosyst. Eng. 2018, 172, 19-28. [CrossRef]

65. Ni, L.; Tian, J.Y.; Shen, C.; Zhao, J. Experimental study of the separation performance of a novel sewage hydrocyclone used in sewage source heat pump. Appl. Therm. Eng. 2016, 106, 1300-1310. [CrossRef]

66. Liu, H.; Ramnarayanan, R.; Logan, B.E. Production of electricity during wastewater treatment using a single chamber microbial fuel cell. Environ. Sci. Technol. 2004, 38, 2281-2285. [CrossRef] [PubMed]

67. Min, B.; Logan, B.E. Continuous electricity generation from domestic wastewater and organic substrates in a flat plate microbial fuel cell. Environ. Sci. Technol. 2004, 38, 5809-5814. [CrossRef] [PubMed]

68. Koga, Y.; Oonuki, H.; Amari, T.; Endo, Y.; Kakurata, K.; Ose, K. Biomass solid fuel production from sewage sludge with pyrolysis and co-firing in coal power plant. Tech. Rev. Mitsubishi Heavy Ind. 2007, 44, 1-5.

69. Oak Ridge National Laboratory. Federal Energy Management Program. Heat Recovery from Wastewater Using a Gravity-Film Heat Exchanger; DOE/EE-0247; Oak Ridge National Laboratory: Oak Riddge, TN, USA, 2005.

70. Shen, C.; Lei, Z.; Yuan, W.; Chenghu, Z.; Yang, Y. A review on the current research and application of wastewater source heat pumps in China. Therm. Sci. Eng. Prog. 2018, 6, 140-156. [CrossRef] 
71. Araz, M.; Hepbasli, A.; Shahrestani, M.; Yao, R.; Essah, E.; Shao, L.; Oliveira, A.C.; Ekren, O.; Günerhan, H. Performance evaluation of a building integrated photovoltaic (BIPV) system combined with a wastewater source heat pump (WWSHP) system. Energy Procedia 2017, 140, 434-446. [CrossRef]

72. Hepbasli, A.; Biyik, E.; Ekren, O.; Gunerhan, H.; Araz, M. A key review of wastewater source heat pump (WWSHP) systems. Energy Convers. Manag. 2014, 88, 700-722. [CrossRef]

73. European Union (EU). Directive 2009/28/EC of the European Parliament and of the Council of 23 April 2009 on the promotion of the use of energy from renewable sources and amending and subsequently repealing directives 2001/77/EC and 2003/30/EC. Off. J. Eur. Union 2009, 140/16, 47.

74. Capodaglio, A.G.; Callegari, A.; Lopez, M.V. European framework for the diffusion of biogas uses: Emerging technologies, acceptance, incentive strategies, and institutional-regulatory support. Sustainability 2016, 8, 298. [CrossRef]

75. Feng, Y.; Li, C.; Zhang, D. Lipid production of Chlorella vulgaris cultured in artificial wastewater medium. Bioresour. Technol. 2011, 102, 101-105. [CrossRef]

76. Janssen, R.; Turhollow, A.F.; Rutz, D.; Mergner, R. Production facilities for second-generation biofuels in the USA and the EU-current status and future perspectives. Biofuels Bioprod. Biorefin. 2013, 7, 647-665. [CrossRef]

77. Zupančič, G.D.; Roš, M. Heat and energy requirements in thermophilic anaerobic sludge digestion. Renew. Energy 2003, 28, 2255-2267. [CrossRef]

78. Samolada, M.; Zabaniotou, A. Potential application of pyrolysis for the effective valorisation of the end of life tires in Greece. Environ. Dev. 2012, 4, 73-87. [CrossRef]

79. Scarlat, N.; Dallemand, J.F.; Motola, V.; Monforti-Ferrario, F. Bioenergy production and use in Italy: Recent developments, perspectives and potential. Renew. Energy 2013, 57, 448-461. [CrossRef]

80. Gollet, P.; Helias, A.; Lardon, L.; Ras, M.; Goy, R.A.; Steyer, J.P. Life-cycle assessment of microalgae culture coupled to biogas production. Bioresour. Technol. 2011, 102, 207-214.

81. Silvestre, G.; Fernńdez, B.; Bonmatí, A. Significance of anaerobic digestion as a source of clean energy in wastewater treatment plants. Energy Convers. Manag. 2015, 101, 255-262. [CrossRef]

82. Li, M.; Zhou, M.; Tian, X.; Tan, C.; McDaniel, C.T.; Hassett, D.J.; Gu, T. Microbial fuel cell (MFC) power performance improvement through enhanced microbial electrogenicity. Biotechnol. Adv. 2018, 36, 1316-1327. [CrossRef]

83. Zhang, F.; Ge, Z.; Grimaud, J.; Hurst, J.; He, Z. Long-term liter-scale microbial fuel cells treating primary effluent installed performance of in a municipal wastewater treatment facility. Environ. Sci. Technol. 2013, 47, 4941-4948. [CrossRef]

84. Dentel, S.; Strogen, B.; Chiu, P. Direct generation of electricity from sludges and other liquid wastes. Water Sci. Technol. 2004, 50, 161-168. [CrossRef]

85. Cieślik, B.M.; Namieśnik, J. Review of sewage sludge management: Standards, regulations and analytical methods. J. Clean. Prod. 2015, 90,1-15. [CrossRef]

86. Heidrich, E.S.; Curtis, T.P.; Dolfing, J. Determination of the internal chemical energy of wastewater. Environ. Sci. Technol. 2011, 45, 827-832. [CrossRef]

87. Rulkens, W. Sewage sludge as a biomass resource for the production of energy: Overview and assessment of the various options. Energy Fuels 2008, 22, 9-15. [CrossRef]

88. Mishra, V.S.; Mahajani, V.V.; Joshi, J.B. Wet air oxidation. Ind. Eng. Chem. Res. 1995, 34, 2-48. [CrossRef]

89. Zaker, A.; Chen, Z.; Wang, X.; Zhang, Q. Microwave-assisted pyrolysis of sewage sludge: A review. Fuel Process. Technol. 2019, 32, 84-104. [CrossRef]

90. Wei, J.T.; Guo, Q.H.; Ding, L.; Yoshikawa, K.; Yu, G.S. Synergy mechanism analysis of petroleum coke and municipal solid waste (MSW)-derived hydrochar co-gasification. Appl. Energy 2017, 206, 1354-1363. [CrossRef]

91. Gollakota, A.R.K.; Kishore, N.; Gu, S. A review on hydrothermal liquefaction of biomass. Renew. Sustain. Energy Rev. 2018, 81, 1378-1392. [CrossRef]

92. Tekin, K.; Karagöz, S.; Bektaş, S. A review of hydrothermal biomass processing. Renew. Sustain. Eneregy Rev. 2014, 40, 673-687. [CrossRef]

93. Samolada, M.; Zabaniotou, A. Comparative assessment of municipal sewage sludge incineration, gasification and pyrolysis for a sustainable sludge-to-energy management in Greece. Waste Manag. 2014, 34, 411-420. [CrossRef]

94. Luck, F. Wet air oxidation: Past, present and future. Catal. Today 1999, 53, 81-91. [CrossRef] 
95. Weemaes, M.; Verstraete, W.H. Evaluation of current wet sludge disintegration techniques. J. Chem. Technol. Biotechnol. 1998, 73, 83-92. [CrossRef]

96. Levec, J.; Pintar, A. Catalytic wet-air oxidation processes: A review. Catal. Today 2007, 124, $172-184$. [CrossRef]

97. Judex, J.W.; Gaiffi, M.; Burgbacher, H.C. Gasification of dried sewage sludge: Status of the demonstration and the pilot plant. Waste Manag. 2012, 32, 719-723. [CrossRef] [PubMed]

98. Li, G.; Wang, Z.; Chan, F.; Wang, J.B. Research progress of oil making from sewage sludge by direct thermochemistry liquefaction technology. J. Tianjin Univ. Sci. Technol. 2009, 24, 74-78.

99. Yang, T.; Liu, X.; Li, R.; Li, B.; Kai, X.P. Hydrothermal liquefaction of sewage sludge to produce bio-oil: Effect of co-pretreatment with subcritical water and mixed surfactants. J. Supercrit. Fluids 2019, 144, 28-38. [CrossRef]

100. Fonts, I.; Juan, A.; Gea, G.; Murillo, M.B.; Sánchez, J.L. Sewage sludge pyrolysis in fluidized bed, 1: Influence of operational conditions on the product distribution. Ind. Eng. Chem. Res. 2008, 47, 5376-5385. [CrossRef]

101. Inguanzo, M.; Menéndez, J.A.; Menéndez, J.A.; Blanco, C.G.; Pis, J.J. On the pyrolysis of sewage sludge: The influence of pyrolysis conditions on solid, liquid and gas fractions. J. Anal. Appl. Pyrolysis 2002, 63, $209-222$. [CrossRef]

102. Yuan, Z.; Olsson, G.; Cardell-Oliver, R.; Schagen, K.; Marchi, A.; Deletic, A.; Urich, C.; Rauch, W.; Liu, Y.C.; Jiang, G.M. Sweating the assets-The role of instrumentation, control and automation in urban water systems. Water Res. 2019, 155, 381-402. [CrossRef]

103. Benedetti, L.; de Baets, B.; Nopens, I.; Vanrolleghem, P.A. Multi-criteria analysis of wastewater treatment plant design and control scenarios under uncertainty. Environ. Modell. Softw. 2010, 25, 616-621. [CrossRef]

104. Traoré, A.; Grieu, S.; Thiery, F.; Polit, M.; Colprim, J. Control of sludge height in a secondary settler using fuzzy algorithms. Comput. Chem. Eng. 2006, 30, 1235-1242. [CrossRef]

105. Lee, H.; Lee, K.M.; Park, C.H.; Park, Y.H. Application of remote monitoring and automatic control system using neural network for small wastewater treatment plants in Korea. Water Sci. Technol. 2005, 51, $249-257$. [CrossRef]

106. Pleau, M.; Colas, H.; Lavallée, P.; Pelletier, G.; Bonin, R. Global optimal real-time control of the Quebec urban drainage system. Environ. Modell. Softw. 2005, 20, 401-413. [CrossRef]

107. Holenda, B.; Domokos, E.; Rédey, Á.; Fazakas, J. Dissolved oxygen control of the activated sludge wastewater treatment process using model predictive control. Comput. Chem. Eng. 2008, 32, 1270-1278. [CrossRef]

108. Cristea, S.; de Prada, C.; Sarabia, D.; Gutiérrez, G. Aeration control of a wastewater treatment plant using hybrid NMPC. Comput. Chem. Eng. 2011, 35, 638-650. [CrossRef]

109. Holenda, B.; Domokos, E.; Rédey, Á.; Fazakas, J. Aeration optimization of a wastewater treatment plant using genetic algorithm. Optimal Control Appl. Methods 2007, 28, 191-208. [CrossRef]

110. Lee, I.; Lim, H.; Jung, B.; Colosimo, M.F.; Kim, H. Evaluation of aeration energy saving in two modified activated sludge processes. Chemosphere 2015, 140, 72-78. [CrossRef] [PubMed]

111. Ferrer, J.; Rodrigo, M.A.; Seco, A.; Penya-roja, J.M. Energy saving in the aeration process by fuzzy logic control. Water Sci. Technol. 1998, 38, 209-217. [CrossRef]

112. Regmi, P.; Miller, M.W.; Holgate, B.; Bunce, R.; Park, H.; Chandran, K.; Wett, B.; Murthy, S.; Bott, C.B. Control of aeration, aerobic SRT and COD input for mainstream nitritation/denitritation. Water Res. 2014, 57, 162-171. [CrossRef]

113. Bo, Y.C.; Zhang, X. Online adaptive dynamic programming based on echo state networks for dissolved oxygen control. Appl. Soft Comput. 2018, 62, 830-839. [CrossRef]

114. Kroll, S.; Dirckx, G.; Donckels, B.M.R.; Dorpe, M.V.; Weemaes, M.; Willems, P. Modelling real-time control of WWTP influent flow under data scarcity. Water Sci. Technol. 2016, 73, 1637-1643. [CrossRef]

115. Fiter, M.; Gúell, D.; Comas, J.; Colprim, J.; Poch, M.; Rodríguez-Roda, I. Energy Saving in a Wastewater Treatment Process: An Application of Fuzzy Logic Control. Environ. Technol. 2005, 26, 1263-1270. [CrossRef]

116. Traorá, A.; Grieu, S.; Puig, S.; Corominas, L.; Thiery, F.; Polit, M.; Colprim, J. Fuzzy control of dissolved oxygen in a sequencing batch reactor pilot plant. Chem. Eng. J. 2005, 111, 13-19. [CrossRef]

117. Han, H.; Qiao, J.F. Adaptive dissolved oxygen control based on dynamic structure neural network. Appl. Soft Comput. 2011, 11, 3812-3820. [CrossRef]

118. Lee, J.M.; Yoo, C.K.; Lee, I.B. New monitoring technique with an ICA algorithm in the wastewater treatment process. Water Sci. Technol. 2003, 47, 49-56. [CrossRef] [PubMed] 
119. Jeppsson, U.; Alex, J.; Pons, M.N.; Spanjers, H.; Vanrolleghem, P.A. Status and future trends of ICA in wastewater treatment-A European perspective. Water Sci. Technol. 2002, 45, 485-494. [CrossRef] [PubMed]

120. Olsson, G. ICA and me-A subjective review. Water Res. 2012, 46, 1585-1624. [CrossRef] [PubMed]

121. Olsson, G.; Nielsen, M.; Yuan, Z.; Lynggaard-Jensen, A.; Steyer, J.P. Instrumentation, Control and Automation in Wastewater Systems; IWA Publishing: London, UK, 2005.

122. Charef, A.; Ghauch, A.; Baussand, P.; Martin-Bouyer, M. Water quality monitoring using a smart sensing system. Measurement 2000, 28, 219-224. [CrossRef]

123. Tong, S.Q.; Tong, M.R.; Twigg, C.M.; Chen, Y.; Sadik, O.A. Energy efficient control for smart wastewater treatment plants using self-powered wireless sensor networks. Sens. Lett. 2013, 11, 1689-1694. [CrossRef]

124. Häck, M.; Wiese, J. Trends in instrumentation, control and automation and the consequences on urban water systems. Water Sci. Technol. 2006, 54, 265-272. [CrossRef]

125. Awe, O.W.; Liu, R.; Zhao, Y. Analysis of energy consumption and saving in wastewater treatment plant: Case study from Ireland. J. Water Sustain. 2016, 6, 63-76.

126. Bell, K.Y.; Abel, S. Optimization of WWTP aeration process upgrades for energy efficiency. Water Pract. Technol. 2011, 6. [CrossRef]

127. Psomopoulos, C.; Barkas, D.; Ioannidis, G.C. The recycling potential of submersible sewage pumps in the EU. Recycling 2018, 3, 14. [CrossRef]

128. Pöhler, M.; Gerlach, S.; Höchel, K.; Mengdehl, T.; Thamsen, P.U. Linking Efficiency to Functional Performance by a Pump Test Standard for Wastewater Pumps. In Proceedings of the ASME 2015 Joint Fluids Engineering Conference, Waikoloa, HI, USA, 2015.

129. Sweetapple, C.; Fu, G.; Butler, D. Multi-objective optimisation of wastewater treatment plant control to reduce greenhouse gas emissions. Water Res. 2014, 55, 52-62. [CrossRef]

130. Flores-Alsina, X.; Arnell, M.; Amerlinck, Y.; Corominas, L.; Gernaey, K.V.; Guo, L.; Lindblom, E.; Nopens, I.; Porro, J.; Shaw, A.; et al. Balancing effluent quality, economic cost and greenhouse gas emissions during the evaluation of (plant-wide) control/operational strategies in WWTPs. Sci. Total Environ. 2014, 1, $466-467$. [CrossRef] [PubMed]

131. Beraud, B.; Steyer, J.P.; Lemoine, C.; Latrille, E.; Manic, G.; Printemps-Vacquier. Towards a global multi objective optimization of wastewater treatment plant based on modeling and genetic algorithms. Water Sci. Technol. 2007, 56, 109-116. [CrossRef] [PubMed]

132. Yousefi, M.; Banihabib, M.E.; Soltani, J.; Roozbahani, A. Multi-objective particle swarm optimization model for conjunctive use of treated wastewater and groundwater. Agric. Water Manag. 2018, 208, 224-231. [CrossRef]

133. Flores-Alsina, X.; Corominas, L.; Snip, L.; Vanrolleghem, P.A. Including greenhouse gas emissions during benchmarking of wastewater treatment plant control strategies. Water Res. 2011, 45, 4700-4710. [CrossRef] [PubMed]

134. Hreiz, R.; Roche, N.; Benyahia, B.; Latifi, M.A. Multi-objective optimal control of small-size wastewater treatment plants. Chem. Eng. Res. Des. 2015, 102, 345-353. [CrossRef]

135. Faria, A.B.B.D.; Ahmadi, A.; Tiruta-Barna, L.; Spérandio, M. Feasibility of rigorous multi-objective optimization of wastewater management and treatment plants. Chem. Eng. Res. Des. 2016, 115, $394-406$. [CrossRef]

136. Ilias, A.; Panoras, A.; Angelakis, A. Wastewater recycling in greece: The case of thessaloniki. Sustainability 2014, 6, 2876-2892. [CrossRef]

137. Ostace, G.S.; Cristea, V.M.; Agachi, P.S. Cost reduction of the wastewater treatment plant operation by MPC based on modified ASM1 with two-step nitrification/denitrification model. Comput. Chem. Eng. 2011, 35, 2469-2479. [CrossRef]

138. Smets, I.Y.; Haegebaert, J.V.; Carrette, R.; Impe, J.F.V. Linearization of the activated sludge model ASM1 for fast and reliable predictions. Water Res. 2003, 37, 1831-1851. [CrossRef]

139. Keskitalo, J.; Leiviskä, K. Evaluating the potential for process control in pulp mill wastewater treatment plant by simulation. IFAC Proc. Vol. 2012, 45, 948-952. [CrossRef]

140. Keskitalo, J.; Jansen, J.l.C.; Leiviskä, K. Calibration and validation of a modified ASM1 using long-term simulation of a full-scale pulp mill wastewater treatment plant. Environ. Technol. 2010, 31, 555-566. [CrossRef] [PubMed] 
141. Ostace, G.S.; Cristea, V.M.; Agachi, P.S. Evaluation of different control strategies of the wastewater treatment plant based on a modified Activated Sludge Model NO. 3. Environ. Technol. 2012, 11, 147-164.

142. Jeppsson, U.; Rosen, C.; Alex, J.; Copp, J.; Gernaey, K.V.; Pons, M.N.; Vanrolleghem, P.A. Towards a benchmark simulation model for plant-wide control strategy performance evaluation of WWTPs. Rev. Water Sci. Technol. 2006, 53, 287-295. [CrossRef] [PubMed]

143. Kim, H.; Lim, H.; Wie, J.; Lee, I.; Colosimo, M.F. Optimization of modified ABA2 process using linearized ASM2 for saving aeration energy. Chem. Eng. J. 2014, 251, 337-342. [CrossRef]

144. Hao, X.; Liu, R.; Huang, X. Evaluation of the potential for operating carbon neutral WWTPs in China. Water Res. 2015, 87, 424-431. [CrossRef]

145. Hiegemann, H.; Herzer, D.; Nettmann, E.; Lübken, M.; Schulte, P.; Schmelz, K.G.; Gredigk-Hoffmann, S.; Wichern, M. An integrated $45 \mathrm{~L}$ pilot microbial fuel cell system at a full-scale wastewater treatment plant. Bioresour. Technol. 2016, 218, 115-122. [CrossRef]

146. Cao, Y.; Pawłowski, A. Sewage sludge-to-energy approaches based on anaerobic digestion and pyrolysis: Brief overview and energy efficiency assessment. Renew. Sustain. Eneregy Rev. 2012, 16, 1657-1665. [CrossRef]

147. O’Brien, M.; Mack, J.; Lennox, B.; Lovett, D.; Wall, A. Model predictive control of an activated sludge process: A case study. Control Eng. Prac. 2011, 19, 54-61. [CrossRef]

148. Gussem, K.D.; Fenu, A.; Gussem, D.K.; Fenu, A.; Wambecq, T.; Weemaes, M. Energy saving on wastewater treatment plants through improved online control: Case study wastewater treatment plant Antwerp-South. Water Sci. Technol. 2014, 69, 1074-1079. [CrossRef]

149. Foladori, P.; Vaccari, M.; Vitali, F. Energy audit in small wastewater treatment plants: Methodology, energy consumption indicators, and lessons learned. Water Sci. Technol. 2015, 76, 1007-1015. [CrossRef] [PubMed]

150. Longo, S.; d'Antoni, B.M.; Bongards, M.; Chaparro, A.; Cronrath, A.; Fatone, F.; Lema, J.M.; Mauricio-Iglesias, M.; Soares, A.; Hospido, A. Monitoring and diagnosis of energy consumption in wastewater treatment plants. A state of the art and proposals for improvement. Appl. Energy 2016, 179, 1251-1268. [CrossRef]

151. Luo, L.; Dzakpasu, M.; Yang, B.; Zhang, W.; Yang, Y.; Wang, X.C. A novel index of total oxygen demand for the comprehensive evaluation of energy consumption for urban wastewater treatment. Appl. Energy 2019, 236, 253-261. [CrossRef]

152. Zhang, X.H.; Cao, J.; Li, J.R.; Deng, S.H.; Zhang, Y.Z.; Wu, J. Influence of sewage treatment on China's energy consumption and economy and its performances. Renew. Sustain. Eneregy Rev. 2015, 49, 1009-1018. [CrossRef]

153. Ji, T.T.; Li, Y.M. Strategy and practice of energy saving and consumption reduction in European sewage treatment plants. China Water Wastewater 2018, 34, 36-41.

154. Kayal, B.; Abu-Ghunmi, D.; Abu-Ghunmi, L.; Archenti, A.; Nicolescu, M.; Larkin, C.; Corbet, S. An economic index for measuring firm's circularity: The case of water industry. J. Behav. Exp. Fin. 2019, 21, 123-129. [CrossRef]

155. Wu, J.G.; Meng, X.Y.; Liu, X.M.; Liu, X.W.; Zheng, Z.X.; Xu, D.Q.; Sheng, G.P.; Yu, H.Q. Life cycle assessment of a wastewater treatment plant focused on material and energy flows. Environ. Manag. 2010, 46, 610-617. [CrossRef]

156. Brus, A.; Perrodin, Y. Identification, assessment and prioritization of ecotoxicological risks on the scale of a territory: Application to WWTP discharges in a geographical area located in northeast Lyon, France. Chemosphere 2017, 189, 340-348. [CrossRef]

157. Bradley, R.B.; Daigger, G.T.; Rubin, R.; Tchobanoglous, G. Evaluation of onsite wastewater treatment technologies using sustainable development criteria. Clean Technol. Environ. Policy 2002, 4, 87-99. [CrossRef]

158. Carducci, A.; Donzelli, G.; Cioni, L.; Federigi, I.; Lombardi, R.; Verani, M. Quantitative microbial risk assessment for workers exposed to bioaerosol in wastewater treatment plants aimed at the choice and setup of safety measures. Int. J. Environ. Res. Public Health 2018, 15, 1490. [CrossRef]

159. Rak, J.R.; Tchórzewska-Cieślak, B.; Pietrucha-Urbanik, K. A hazard assessment method for waterworks systems operating in self-government units. Int. J. Environ. Res. Public Health 2019, 16, 767. [CrossRef] [PubMed]

160. Palli, L.; Spina, F.; Varese, G.C.; Vincenzi, M.; Aragno, M.; Arcangeli, G.; Mucci, N.; Santianni, D.; Caffaz, S.; Gori, R. Occurrence of selected pharmaceuticals in wastewater treatment plants of Tuscany: An effect-based approach to evaluate the potential environmental impact. Int. J. Hyg. Environ. Health 2019, 222, 717-725. [CrossRef] [PubMed] 
161. Liu, H.; Wang, H.; Zhou, X.; Fan, J.; Liu, Y.; Yang, Y. A comprehensive index for evaluating and enhancing effective wastewater treatment in two industrial parks in China. J. Cleaner Prod. 2019, 230, 854-861. [CrossRef]

162. Longo, S.; Mauricio-Iglesias, M.; Soares, A.; Campo, P.; Fatone, F.; Eusebi, A.L.; Akkersdijk, E.; Stefani, L.; Hospido, A. ENERWATER-A standard method for assessing and improving the energy efficiency of wastewater treatment plants. Appl. Energy 2019, 242, 897-910. [CrossRef]

163. Geng, Z.Q.; Dong, J.G.; Han, Y.M.; Zhu, Q.X. Energy and environment efficiency analysis based on an improved environment DEA cross-model: Case study of complex chemical processes. Appl. Energy 2017, 205, 465-476. [CrossRef]

164. Wang, S.; Qiu, S.; Ge, S.; Liu, J.; Peng, Z. Benchmarking Toronto wastewater treatment plants using DEA window and Tobit regression analysis with a dynamic efficiency perspective. Environ. Sci. Pollut. Res. 2018, 25, 32649-32659. [CrossRef]

165. Castellet, L.; Molinos-Senante, M. Efficiency assessment of wastewater treatment plants: A data envelopment analysis approach integrating technical, economic, and environmental issues. J. Environ. Manag. 2016, 167, 160-166. [CrossRef]

166. Li, M.J.; Tao, W.Q. Review of methodologies and polices for evaluation of energy efficiency in high energy-consuming industry. Appl. Energy 2017, 187, 203-215. [CrossRef]

167. Guerrini, A.; Romano, G.; Indipendenza, A. Energy efficiency drivers in wastewater treatment plants: A double bootstrap DEA analysis. Sustainability 2017, 9, 1126. [CrossRef]

168. Chung, W. Review of building energy-use performance benchmarking methodologies. Appl. Energy 2011, 88, 1470-1479. [CrossRef]

169. Pasqualino, J.C.; Meneses, M.; Abella, M.; Castells, F. LCA as a decision support tool for the environmental improvement of the operation of a municipal wastewater treatment plant. Environ. Sci. Technol. 2009, 43, 3300-3307. [CrossRef] [PubMed]

170. Li, Y.; Luo, X.; Huang, X.; Wang, D.; Zhang, W. Life cycle assessment of a municipal wastewater treatment plant: A case study in Suzhou, China. J. Clean. Prod. 2013, 57, 221-227. [CrossRef]

171. Santoyo-Castelazo, E.; Azapagic, A. Sustain ability assessment of energy systems: Integrating environmental, economic and social aspects. J. Cleaner Prod. 2014, 80, 119-138. [CrossRef]

172. Lorenzo-Toja, Y.; Vázquez-Rowe, I.; Chenel, S.; Marín-Navarro, D.; Moreira, M.T.; Feijoo, G. Eco-Efficiency analysis of Spanish WWTPs using the LCA + DEA method. Water Res. 2015, 68, 651-666. [CrossRef]

173. Massoud, M.A.; Tarhini, A. Decentralized approaches to wastewater treatment and management: Applicability in developing countries. J. Environ. Manag. 2009, 90, 652-659. [CrossRef]

174. Willis, J.; Stone, L.; Durden, K.; Beecher, N.; Hemenway, C.; Greenwood, R. Barriers to Biogas Use for Renewable Energy; Water Environment Research Foundation: Alexandria, VA, USA, 2012.

175. Cui, J.H.; Fan, M.Y. Problems and countermeasures of investment in sewage treatment construction projects. China Water Wastewater 2001, 17, 36-38.

176. Jung, Y.T.; Narayanan, N.C.; Cheng, Y.L. Cost comparison of centralized and decentralized wastewater management systems using optimization model. J. Environ. Manag. 2018, 213, 90-97. [CrossRef]

177. Brand, N.; Ostfeld, A. Optimal design of regional wastewater pipelines and treatment plant systems. J. Water Environ. Res. 2011, 83, 53-64. [CrossRef]

178. Leitao, J.; Matos, J.; Gonçalves, A.; Matos, J. Contribution of geographic information systems and location models to planning of wastewater systems. J. Water Sci. Technol. 2006, 52, 1-8. [CrossRef]

179. Yoshida, H.; Mønster, J.; Scheutz, C. Plant-integrated measurement of greenhouse gas emissions from a municipal wastewater treatment plant. Water Res. 2014, 61, 108-118. [CrossRef]

180. Kyung, D.; Kim, M.; Chang, J.; Lee, W. Estimation of greenhouse gas emissions from a hybrid wastewater treatment plant. J. Cleaner Prod. 2015, 95, 117-123. [CrossRef]

181. Gasperi, J.; Dris, R.; Rocher, V.; Tassin, B. Microplastics in the continental area: An emerging challenge. Norman Bull. 2015, 4, 18-19.

182. Rosi-Marshall, E.J.; Royer, T.V. Pharmaceutical compounds and ecosystem function: An emerging research challenge for aquatic ecologists. Ecosystems 2012, 15, 867-880. [CrossRef]

183. Mutiyar, P.K.; Mittal, A.K. Risk assessment of antibiotic residues in different water matrices in India: Key issues and challenges. Environ. Sci. Pollut. Res. 2014, 21, 7723-7736. [CrossRef] [PubMed]

184. Ternes, T. The occurrence of micopollutants in the aquatic environment: A new challenge for water management. Water Sci. Technol. 2007, 55, 327-332. [CrossRef] 
185. Zadorojniy, A.; Wasserkrug, S.; Zeltyn, S.; Lipets, V. IBM cognitive technology helps aqualia to reduce costs and save resources in wastewater treatment. INFORMS J. Appl. Anal. 2017, 47, 411-424. [CrossRef]

186. Ariunbaatar, J.; Panico, A.; Esposito, G.; Pirozzi, F.; Lens, P.N.L. Pretreatment methods to enhance anaerobic digestion of organic solid waste. Appl. Energy 2014, 123, 143-156. [CrossRef]

187. Hendriks, A.T.W.M.; Zeeman, G. Pretreatments to enhance the digestibility of lignocellulosic biomass: A review. Bioresour. Technol. 2009, 1, 10-18. [CrossRef]

188. Del Rio, A.V.; Morales, N.; Isanta, E.; Mosquera-Corral, A.; Campos, J.L.; Steyer, J.P.; Carrère, H. Thermal pretreatment of aerobic granular sludge: Impact on anaerobic biodegradability. Water Res. 2011, 45, 6011-6020. [CrossRef]

189. Ma, J.; Duong, T.H.; Smits, M.; Verstraete, W.; Carballa, M. Enhanced biomethanation of kitchen waste by different pre-treatments. Bioresour. Technol. 2011, 102, 592-599. [CrossRef]

190. Carlsson, M.; Lagerkvist, A.; Morgan-Sagastume, F. The effects of substrate pretreatment on anaerobic digestion: A review. Bioresour. Technol. 2012, 32, 1634-1650.

191. Cesaro, A.; Belgiorno, V. Pretreatment methods to improve anaerobic biodegradability of organic municipal solid waste fractions. Chem. Eng. J. 2014, 240, 24-37. [CrossRef]

192. Nowak, O.; Keil, S.; Fimml, C. Examples of energy self-sufficient municipal nutrient removal plants. Water Sci. Technol. 2011, 64, 1-6. [CrossRef] [PubMed]

(C) 2019 by the authors. Licensee MDPI, Basel, Switzerland. This article is an open access article distributed under the terms and conditions of the Creative Commons Attribution (CC BY) license (http://creativecommons.org/licenses/by/4.0/). 